\title{
IS GLOBALIZATION TODAY REALLY DIFFERENT THAN GLOBALIZATION A HUNDRED YEARS AGO?
}

\author{
Michael D. Bordo \\ Barry Eichengreen \\ Douglas A. Irwin \\ Working Paper 7195 \\ http://www.nber.org/papers/w7195 \\ NATIONAL BUREAU OF ECONOMIC RESEARCH \\ 1050 Massachusetts Avenue \\ Cambridge, MA 02138 \\ June 1999
}

This paper was prepared for the Brookings Trade Policy Forum on "Governing in a Global Economy," Washington, D.C., April 15-16, 1999. Conference and post-conference discussants, especially Ralph Bryant, Charles Calomiris, Rudi Dornbusch, Jeff Frankel, Charles Goodhart, and Alan Taylor, inundated us with useful comments, for which we are grateful. We thank Qiming Chen, Antu Murshid, Zhu Wang, and Carlos Arteta for valuable research assistance. All opinions expressed are those of the authors and not those of the National Bureau of Economic Research.

(C) 1999 by Michael D. Bordo, Barry Eichengreen, and Douglas A. Irwin. All rights reserved. Short sections of text, not to exceed two paragraphs, may be quoted without explicit permission provided that full credit, including $(\mathcal{C}$ notice, is given to the source. 
Is Globalization Today Really Different than

Globalization a Hundred Years Ago?

Michael D. Bordo, Barry Eichengreen, and Douglas A. Irwin

NBER Working Paper No. 7195

June 1999

JEL No. F13, F21, F15, N20, E32

\section{ABSTRACT}

This paper pursues the comparison of economic integration today and pre 1914 for trade as well as finance, primarily for the United States but also with reference to the wider world. We establish the outlines of international integration a century ago and analyze the institutional and informational impediments that prevented the late nineteenth century world from achieving the same degree of integration as today. We conclude that the world today is different: commercial and financial integration before World War I was more limited. Given that integration today is even more pervasive than a hundred years ago, it is surprising that trade tensions and financial instability have not been worse in recent years. In the conclusion we point to the institutional innovations that have taken place in the past century as an explanation. This in turn suggests the way forward for national governments and multilaterals.

Michael D. Bordo

Department of Economics

Rutgers University

New Brunswick, NJ 08901

and NBER

bordo@fas-econ.rutgers.edu
Barry Eichengreen

Department of Economics

University of California

549 Evans Hall 3880

Berkeley, CA 94720-3880

and NBER

eichengr@econ.berkeley.edu

Douglas A. Irwin

Department of Economics

Dartmouth College

Hanover, NH 03755

douglas.irwin@dartmouth.edu 
The effects of globalization — on the United States and more generally — is the topic of the day. Officials, academics and market participants all sense that the integration of national economies and the development of international markets have gone further than ever before. The extent of integration in turn creates a growing sense of helplessness about the ability of nations to control their destinies in the face of global markets. Does the growth of global markets pose a threat to distinctive national social systems? Does a world characterized by high levels of trade and large international capital flows jeopardize social cohesion and economic and financial stability and therefore require the strengthening of national safety nets and international institutions, perhaps including a world financial regulator and an international lender of last resort, or can private markets develop mechanisms for containing these risks? And, failing this, will governments retreat toward financial autarchy and succumb to populist pressures for trade protectionism?

The idea that globalization today is unprecedented (if not necessarily the preceding paragraph's pessimistic vision) is implicit in publications like Lawrence, Bressand and Ito (1996) and much informed policy discussion. But there is also an undercurrent which recognizes that there existed a previous period of globally-integrated markets. A hundred years ago, it is suggested, prior to the disruptions of two world wars and the collapse of commodity and financial markets in a global depression, markets were every bit as internationalized as today. If we have just gone "back to the future," simply matching the degree of economic integration experienced a century ago, globalization may not be so unprecedented after all. 
This view has been expressed by several prominent economists. Zevin (1992, p. 43), for example, believes that "while financial markets have certainly tended toward greater openness since the end of the Second World War, they have reached a degree of integration that is neither dramatic nor unprecedented in the larger historical context of several centuries." Sachs and Warner (1995, p. 5) argue that "the reemergence of a global, capitalist market economy since 1950, and especially since the mid-1980s, in an important sense reestablishes the global market economy that had existed one hundred years earlier." Rodrik (1998, p. 2) concludes that "in many ways, today's world falls far short of the level of economic integration reached at the height of the gold standard."

For those willing to pursue it, these observations lead to the question of why globalization a century ago did not create the same dilemmas as now. Was the difference the greater insulation policy makers enjoyed, in an era of limited democratization, from rent seeking and political pressure? Was it, as George Soros (1998) — and Charles Kindleberger before him — would have it, that there existed a great power (Britain) willing to provide open markets for the exports of the developing world, a stable monetary framework (the gold standard) to prevent currency fluctuations at the center from destabilizing conditions at the periphery, and an ideological consensus (faith in reason, respect for science, Judeo-Christian ethics) to create a basis for international collaboration?

Or was the difference that markets were not in fact as profoundly integrated a hundred years ago, freeing governments of some of the dilemmas that now confront them? This is our conclusion in a previous paper on the globalization of finance (Bordo, Eichengreen and Kim 1998). While financial markets were significantly integrated a hundred years ago, the breadth of 
that integration, we posited, paled in comparison with today. If this view is correct, then differences between the late-nineteenth century and the late-twentieth century reflect not merely differences in the institutional framework but also very real differences in the extent of integration. $^{1}$

Or was it that the dilemmas of globalization were not in fact absent? Much of the recent literature invoking the comparison with the late-19th century asserts that trade conflicts and financial crises were less disruptive than today. It is worth asking whether this is an appropriate presumption. That the first age of globalization ultimately collapsed in a great depression in which trade warfare and a global financial crisis played prominent parts suggests that we should not take this presumption for granted.

This paper pursues the comparison of economic integration now and then for trade as well as finance, primarily for the United States but with reference to the wider world. We establish the outlines of international integration a century ago and analyze the institutional and informational impediments that prevented the late nineteenth century world from achieving the same degree of integration as today. We conclude that our world is different: commercial and financial integration before World War I was more limited. Globalization today raises new issues of governance not just because it is conjoined with a political system which gives a louder voice to special interests, but because the economic phenomenon itself is different: integration is deeper

${ }^{1}$ We are not the only authors who subscribe to this seemingly iconoclastic view. See, for example, Bairoch and Kozul-Wright (1996), Wheeler and Pozo (1997), and (from a different perspective) Baldwin and Martin (1999). 
and broader than a hundred years ago. ${ }^{2}$

Section 1 analyzes international trade in goods and services. We show that while production of tradeable merchandise constituted a larger share of overall economic activity a century ago, trade played a much smaller role in that production than today. Furthermore, trade and direct investments have opened up what a century ago were "non-traded" sectors, such as services, retail trade, and public utilities, to international competition. In both senses, then, trade is more important today. In Section 2 we seek to account for the more limited extent of commercial intercourse a hundred years ago by describing changes in transportation costs, government trade barriers, and information asymmetries that previously served as obstacles to deeper integration. In Section 3 we describe trade tensions in the late $19^{\text {th }}$ century, establishing that they were as prevalent as today.

Sections 4 through 6 reconsider financial integration. Long-term capital flows, we show in Section 4, were large in volume but - just as in the case of trade — limited to narrow sectors of the economy, while short-term flows remained very much lower relative to the size of the world economy. Section 5 attempts to account for these lower levels of financial integration a hundred years ago by describing the information, contracting, and macroeconomic obstacles to deeper integration and the institutions and arrangements that grew up to surmount them. This discussion sheds light on what has changed over the intervening century and what remains to be

${ }^{2}$ As we shall see, the questions that flow from this finding are important. Can countries accommodate the pressures of globalization without engendering a backlash against the open international trade and financial system whose origins date from the end of World War II? Are international institutions such as the International Monetary Fund (IMF) and World Trade Organization (WTO) well designed to accommodate the stresses on the system? And are domestic institutions well configured to ensure ongoing political support for a liberal international trade and financial regime? 
changed to create a system of stable, efficiently-operating international markets. ${ }^{3}$

What tariff wars are for trade, banking and currency crises are for finance. In Section 6 we ask whether crises were as prevalent and devastating a hundred years ago when financial markets were last well integrated internationally. The most serious episodes combined banking with currency crises and were centered in the emerging markets of the era. But while the crisis problem is not new, the drop in output following the typical pre-1914 crisis was somewhat less severe than today. On the other hand, we find that post-crisis recovery is faster today, with the notable exception of pure currency crises, where the gold-standard "resumption rule" had an important stabilizing effect.

What is surprising, in a sense, given that integration is even deeper than a hundred years ago, is that the trade tensions and financial instability of our day have not been worse. In the conclusion we point to the institutional innovations that have taken place in the interim as an explanation for this pattern. This in turn suggests the way forward for national governments and multilaterals.

\section{Commercial Integration Then and Now}

The simplest measure of the importance of trade is its share in GDP. Figure 1 shows U.S. merchandise exports and imports as a share of GNP or GDP from 1869 to 1997. This figure has been interpreted either as showing that trade is roughly as important now as it was a century ago,

${ }^{3}$ Our framework is quite similar to that developed independently by Hermalin and Rose (1999), who emphasize the role of asymmetric information and imperfect contract enforcement in segmenting international markets even today. Hence the emphasis in the text not only on "what has changed" over the intervening century but also on "what remains to be changed." 
or as showing that trade is more important now than it was a century ago. The first interpretation points out that merchandise exports stood at about seven percent of GNP in the late nineteenth century and are about eight percent now, hardly a dramatic difference. The second notes that the trade ratio has been rising since the mid-1980s and now exceeds any level achieved in the late nineteenth or early twentieth century. Krugman (1995, p. 331) presents a balanced interpretation of such figures when he writes: "the general picture of world integration that did not exceed earlytwentieth century levels until sometime well into the 1970s is thus broadly confirmed. In the last decade or so, the share of trade in world output has finally reached a level that is noticeably above its former peak. Nonetheless, it would be hard to argue that the sheer volume of trade is now at a level that marks a qualitative difference from previous experience."

In our view, trade today is strikingly more important than a century ago. Three indicators sustain this view: (a) a higher share of trade in tradeables production, (b) the growth of trade in services, and (c) the rise of production and trade by multinational firms.

Trade in Goods. When the broad merchandise trade figures just mentioned are probed further, they reveal that trade is substantially more important now than a century ago for those sectors engaged in trade. The GDP denominator is typically disaggregated into the following sectors: agriculture, forestry, and fisheries; mining; construction; manufacturing; transportation and public utilities; wholesale and retail trade; finance, insurance, and real estate; other services; and government. Only agriculture, mining, and manufacturing are significant producers of goods that enter into standard merchandise trade statistics. And the sectoral composition of U.S. GDP 
has shifted away from the production of merchandise goods toward the production of services. ${ }^{4}$ Broadly speaking, the share of tradeable goods in national income has been sliced in half over the past century. In both 1899-1903 and 1950, agriculture, mining, and manufacturing comprised about 40 percent of GNP; the comparable figure for 1997 was 20 percent. $^{5}$ While the merchandise trade to GDP ratio a century ago was roughly comparable to what it is today, trade is now much larger as a share of tradeable goods production. In a sense, this means that trade is potentially less important than a century ago because non-traded goods loom larger in national production and consumer demand. (In the next subsection, however, we discuss how previously non-traded services have become increasingly tradeable and subject to international competition.) At the same time, however, the relatively constant share of merchandise trade to GDP masks the increasing importance of trade within the traded-goods sector.

Figure 2 illustrates the dramatic difference between the merchandise trade to GDP ratio and merchandise trade to merchandise output (value added) ratio. The modest change in the ratio of exports to GDP misses the post-war surge in merchandise exports as a share of merchandise production. While the ratio of exports to tradeables production was never much more than 20 percent in the late nineteenth century, it is now more than 40 percent. Feenstra (1998) shows that this same trend is evident in many other OECD countries as well. ${ }^{6}$

${ }^{4}$ The more rapid productivity growth in goods-producing sectors, a shift in demand toward services (such as health care), and the rise of government spending have all contributed to this result.

${ }^{5}$ U.S. Bureau of the Census (1975), series F250-254, F130-134. Council of Economic Advisers (1999), Table B-12.

${ }^{6}$ The export figures are measured on the basis of gross value, while the production data (for agriculture, mining, and manufacturing) from the national income accounts are based on value 
Examining particular commodities reveals the same phenomena. Table 1 compares exports as a share of domestic shipments (output) and imports as a share of total supply (domestic output plus imports) for selected commodities in 1909 and 1993. ${ }^{7}$ Taking either the share of domestic production shipped overseas or the fraction of imports to domestic demand as indicating the importance of trade, its economic role is much more prominent in 1993 than in 1909. This is especially true for manufactured goods, such as machinery and transportation equipment, which a century ago scarcely entered into trade. Even for the bulk-traded staple products of a century ago, such as corn, wheat, coal, and tobacco, international commerce is much larger today as a share of production. Similarly, imports of such products as wool, leather, and manufactured goods are currently more substantial than a century ago.

On the basis of the sheer volume of goods leaving and entering the country, therefore, the United States engages in significantly more international trade today. Before accepting these figures as demonstrating the greater importance of trade today, however, one caveat should be noted: the volume of goods exchanged between different markets may not reflect the degree of market integration. O'Rourke and Williamson (1999) suggest that "it is the cost of moving goods between markets that counts" and that therefore price differentials between markets should be

added data. It would be therefore incorrect to say that over 40 percent of U.S. merchandise production was exported in 1997. The value of trade relative to production may be inflated if intermediate products cross international borders multiple times in the production process. Hummels, Rapoport, and Yi (1998) examine the increasing trade in intermediate products and components ("vertical specialization") and conclude that it accounts for only a part of the recent growth in trade.

${ }^{7}$ The years 1909 and 1993 have been chosen because 1909 was when the last Census of Manufactures was conducted prior to World War I, and 1993 marks the most recent publication of the Bureau of the Census publication U.S. Commodity Exports and Imports as Related to Output. 
examined. ${ }^{8}$ Doing this for the late-nineteenth century Atlantic economy, they find dramatic convergence in the prices of many commodities. In 1870, for example, the Liverpool price of wheat exceeded that in Chicago by about 60 percent; by about 1912, that Liverpool/Chicago price gap had fallen to about 15 percent. The same convergence in goods prices occurred for many other tradeable commodities and manufactures.

Today, basic agricultural commodities and raw materials such as wheat and petroleum are exchanged on organized global markets. The question is not whether there has been price convergence in recent years, but how closely the strictest test of market integration, namely the law of one price, holds. Goodwin (1992) examines wheat prices at five major markets — the United States Gulf export price, Canada's Pacific Coast export price, at the Netherland's Rotterdam exchange, Australia's export price, and Japan's import price — and finds that, after accounting for freight rates, the law of one price holds. Local market prices, of course, may differ due to import tariffs, domestic price supports, or transportation charges, but well-integrated international markets establish a base reference price (often in dollars) for such commodities. In manufactured goods, such price comparisons are difficult to undertake due to the difficulty of uncovering data on like goods. ${ }^{9}$

Trade in Services. The previous section noted that the U.S. economy has shifted toward

${ }^{8}$ They (p. 31) argue that the volume of trade is an unsatisfactory index of commodity market integration because "trade volumes can increase for reasons completely unrelated to commodity market integration and they can decline for reasons completely unrelated to commodity market disintegration."

${ }^{9}$ Goldberg and Verboven (1999) examine the European car market and find that price discrimination is rampant and has not diminished over the 1980-1993 time period. They anticipate, however, that the Euro will diminish intra-European car price differentials. 
producing more services. Once considered largely non-tradeable, services have of course become an increasingly important component of U.S. trade. The value of U.S. service exports (excluded from the merchandise trade figures considered above) now amount to about 40 percent of the value of merchandise exports. The addition of trade in services raises our view of the economic importance of trade: in 1997, the broader figure of exports of goods and services as a percent of GDP stood at 11.9 percent, of which merchandise exports were 8.5 percent and service exports were 3.4 percent. In the 1960 s, by contrast, service exports were just 1.0 percent of GNP and amounted to about 30 percent of merchandise exports.

There are no comparable figures for trade in services for the pre-World War I period, in part because such trade was significantly smaller than today. In 1900, shipping and tourism receipts amounted to just 3 percent of U.S. merchandise exports, according to balance of payments data from Simon (1960, pp. 704-5), compared to about 16 percent of merchandise exports today. Shipping and tourism remain the two largest categories of U.S. service exports, accounting for over 40 percent of such exports. Data on other service exports are not readily available for the pre-1913 period, but those exports were probably minuscule. The other major service exports today are royalties and fees (receipts from intellectual property rights, such as trademarks, patents, and copyrights) and military transfers, categories which were probably not important around the turn of the century. "Other private services," including education, finance, insurance, telecommunications, and business, professional, and technical services, are the most rapidly growing category of U.S. service exports, but they too had no substantial counterpart a century ago.

We can also trace the rise of service exports as a share of services production, as we did in 
the case of tradeable merchandise. In 1960, the ratio of service exports to services value-added was 1.7 percent. By 1997, that ratio had risen to 5.1 percent. While low in comparison to the merchandise "tradeables" sector, this ratio has been rising rapidly and portends even greater trade in services in the future.

The Role of Multinational Trade and Production. Production and exchange by multinational firms has been a force in global trade since the days of the East India Company. There has been a quantum leap, however, in the importance of multinationals from the pre-World War I era.

While there were sizeable capital flows between countries in the pre-1913 world, as we discuss below, most of the flows were portfolio investment and not trade- or production-related direct investments. Multinational enterprises existed in the late nineteenth century, but they were exceptional. As Wilkins (1970, p. 207) concludes: “The skeptic's claim that for major U.S. enterprises of the pre-World War I years foreign business was simply peripheral to domestic investment seems to be supported by the evidence. It does seem that with the exception of Standard Oil of New Jersey, Singer Sewing Machine, International Harvester, New York Life, and perhaps a handful of other large companies, foreign activities did not make a substantial contribution to the profits of U.S. enterprises. In 1914 the vast majority of American corporations were not multinational (this is true today [1970] as well)."

This situation has changed dramatically. The value of direct investments has soared since the early-1980s and is now a quantum leap above a century ago. Table 2 presents the value of direct investments, both by the United States in other countries and by other countries in the United States, as a share of U.S. GNP. U.S. direct investment abroad was remarkably similar in 
1914, 1929, and 1960 at about 6 percent of GNP, but since then has jumped by a factor of three. Similarly, foreign direct investment in the United States, although larger in 1914 than in 1929 or 1960 , rose dramatically by the mid-1990s.

Direct investment can, in principle, complement or substitute for trade in goods. Collins, O'Rourke, and Williamson (1997) find that trade and capital flows were rarely substitutes and frequently complements in the late nineteenth century. Goldberg and Klein (1997) reach a similar finding for the present day. One reason is that multinationals are conduits for trade. A sizeable fraction of U.S. trade is intra-firm trade conducted by multinationals. In 1994, about 36 percent of U.S. exports were intra-multinational transactions (sales to affiliates abroad), as were about 43 percent of U.S. imports (see Zeile 1997). These figures have not changed much since the first government survey in 1977. Multinationals' share of U.S. trade has fallen in recent years, however, and this masks an intensification of those multinationals in intra-firm transactions (i.e., an increasing share of their exports and imports are intra-firm). As we speculate below, multinational corporations mitigate informational barriers to exchange and thus serve to expand international trade.

Direct investments have increasingly exposed services to international competition. U.S. firms can deliver their services to foreign customers either through cross-border transactions (service exports) or through sales by their foreign affiliates. To the extent that certain services cannot be directly traded across borders, direct investments enable U.S. and foreign service providers to enter into each others' market and add an element of international competition to this "non-traded" sector. According to the Census Bureau, service exports, until recently, had been higher than affiliate sales. Higher affiliate sales reflect the fact that about 50 percent of U.S. direct 
investment abroad is now in services sectors, notably banking, finance, insurance, wholesale and retail trade, and other services. U.S. investment has particularly increased in foreign utilities, particularly energy and telecommunications providers.

The shift in U.S. direct investments toward services marks another big difference from a century ago. Back then, the bulk of U.S. investment abroad went into the development of natural resources and raw materials in other parts of the world. In 1914, over 40 percent of U.S. direct investment abroad was in the mining and petroleum sectors, and manufacturing and services (mainly railroads and utilities) each accounted for roughly 20 percent of U.S. direct investment. Today, about half of U.S. direct investments are in services and another 35 percent in manufacturing.

Thus, international direct investments serve as a powerful force for integration that was largely absent (or mainly confined to raw materials development) a century ago. Such investments not only facilitate trade but bring about greater international competition in precisely those sectors whose services are difficult to exchange across borders.

Competing Perspectives. In a 1995 Brookings Paper, Paul Krugman (1995) also considered the features of trade today that distinguish it from a century ago. Krugman wrote that, "while the overall volume of trade has not increased as much as might be expected, the aggregates conceal several novel features of modern international trade," and that "it is possible to identify at least four new aspects of modern world trade — new in the sense that they did not have counterparts in the previous golden age of the global economy." These are the (a) rise of intraindustry trade, (b) ability of producers to break production geographically, (c) emergence of countries with high trade-GDP ratios, (d) large exports of manufactured goods from low- to high- 
wage countries.

Under closer scrutiny, several of these factors do not appear to be distinctive attributes of international trade today. The rise of intra-industry trade is not simply a post-World War II phenomena. In 1997, about 80-85 percent of U.S. exports and imports were classified as manufactured goods. But in 1909, 60 percent of U.S. exports and over 50 percent of U.S. imports were also considered manufactured or semi-manufactured goods. ${ }^{10}$ Thus, both then and now the United States experienced substantial two-way trade in manufactured goods. While the share of manufactures in U.S. trade rose between 1909 and 1995, manufactured exports and imports appear roughly matched at comparable magnitudes in both periods.

We are not aware of any analysis of the relative importance of intra-industry trade over such a long time horizon, so using data from 1909 and 1995 we calculate the standard GrubelLloyd measure of intra-industry trade:

$$
1-\sum\left|\mathrm{X}_{\mathrm{i}}-\mathrm{M}_{\mathrm{i}}\right| / \sum\left(\mathrm{X}_{\mathrm{i}}+\mathrm{M}_{\mathrm{i}}\right)
$$

where $\mathrm{X}_{\mathrm{i}}$ and $\mathrm{M}_{\mathrm{i}}$ are exports and imports at some level of disaggregation. ${ }^{11}$ This formula takes the value of 1 if all trade is intra-industry trade and the value of 0 if all trade is inter-industry trade. Adjusting the index for aggregate trade imbalances, we find a Grubel-Lloyd measure of 0.78 for 1995 and 0.53 for 1909 . While this is not a statistical test, so we do not know how "close" the

${ }^{10}$ U.S. Bureau of the Census (1975), series U213-224. As previously noted, in comparing trade today with that roughly a century ago, we will often use the 1909 year as a basis of comparison. Census data on output are available for this year, the last year such a census was held before World War I.

${ }^{11}$ The 1996 Statistical Abstract of the United States presents data on U.S. exports and imports at the 2-digit SIC level for manufactures for 1995, which we matched that to data presented in the 1913 Statistical Abstract for 1909, yielding roughly 15 comparable sectors. 
1909 figure is to the 1995 one, it would appear that we now experience somewhat more intraindustry trade, although the contrast is not as stark as sometimes supposed. ${ }^{12}$

The contention that the United States is more engaged in trade with low-wage developing countries now than a century ago is also not obviously true. Then and now, most of U.S. trade is conducted with developed countries. In 1909, 55.9 percent of U.S. imports in 1909 came from developed countries, taken to be Canada and Europe. In 1995 that figure (now including Japan) was 61.2 percent. Thus, about 40 percent of U.S. imports both now and a century ago comes from developing countries. ${ }^{13}$ Krugman is correct, however, in that the commodity composition of that trade has changed significantly. A century ago U.S. trade with Latin American and Asian economies consisted of agricultural commodities that the United States did not produce in quantity, such as sugar, coffee, tea, etc. Today the U.S. is more likely to be importing manufactured goods from those countries. A classic instance is Mexico: currently over 80 percent of U.S. imports from Mexico are manufactured goods; a century ago the figure was less than ten percent.

Krugman also identifies the emergence of small states with high trade/GDP ratios as distinctive of current day globalization. The data required to assess this point is difficult to come by, but the rise of a few large entrepôt economies with extraordinary trade to GDP ratios, such as Singapore and Hong Kong, probably does not constitute a defining difference between global

\footnotetext{
${ }^{12}$ Becuwe and Messerlin (1986) examine late nineteenth century French intra-industry trade and find that such trade grew until the 1880s and then leveled off.

${ }^{13}$ The pattern of U.S. exports has shifted toward developed countries. In 1909, 59.7 percent of U.S. exports were destined for Canada, Europe, and Japan; in 1995, just over 80 percent were.
} 
trade today and a century ago. A century ago, Carribean, Chinese, and African ports were open for trade and served as flourishing entrepôts, largely transshipping goods produced elsewhere. This is also true today. The WTO, for example, lists Hong Kong as the world $10^{\text {th }}$ largest exporter in 1997 with exports of $\$ 188$ billion, but of this only $\$ 27$ billion were domestic exports.

\section{Why is Commercial Integration Greater Today?}

Why is trade relative to the production of merchandise goods so much greater than a century ago? The simple answer is the barriers that inhibit trade and prevent exchange from taking place are lower today than a century ago. Late nineteenth century integration was propelled by a rapid decline in transportation costs. These costs have remained low, and in the post-war period have been supplemented by policy measures to reduce tariff and non-tariff barriers to trade.

Transport Costs. In the second half of the nineteenth century, transportation costs fell significantly and were a major force for integrating world markets. O'Rourke and Williamson (1994) note that, between 1870 and 1913, the freight rate index on U.S. export routes fell by more than 40 percent when deflated by the general U.S. price index. A wheat-specific freight index fell over 50 percent over the same period. An equally large reduction in land transport costs took place due to railroads, which reduced interior-to-seaboard prices as much if not more than overseas routes. These transport cost declines set the stage for the convergence in tradedgoods prices discussed above.

Transportation costs have not reversed course but have continued to fall. There is some dispute, however, about whether the postwar period has seen a reduction in transportation costs 
comparable to that a century ago. Lundgren $(1996$, p. 7$)$ maintains that the post-war period has seen a sharp reduction in shipping costs. "During the last 30 years merchant shipping has actually undergone a revolution comparable to what happened in the late nineteenth century."

Containerization, bulk shipping, and other innovations have cut loading times and resulted in efficiencies that have propelled these cost reductions. Hummels (1999) disputes this conclusion. He finds that there has been little decline in shipping costs (perhaps even an increase), certainly not enough to have played a major role in accelerating international trade.

Air transport, however, has been displacing shipping as the means of moving goods in international trade. The share of U.S. imports that arrives via air has risen from 8.8 percent in 1974 to 19.0 percent in 1996. Similarly, nearly a third of U.S. exports (including aircraft) leave via air. Shipping via air has been largely a post-war phenomena and has seen substantial cost reductions. Hummels (1999) finds that air cargo rates on long distant routes have declined by about 15-20 percent (when deflated by U.S. import price index) over the 1975-93 period.

Even if transport costs have not fallen as dramatically as they did in the late 19th century, they have remained low. In addition, technological changes have expanded the array of delivery mechanisms and cut the time to delivery in ways that have brought an ever increasing variety of goods (cut flowers from Central America, lobsters from Maine) into world commerce.

Trade Barriers. Evidence on tariff barriers indicates that these have been dramatically reduced. Table 3 presents measures of average tariffs on manufactured goods for selected countries and years over the past century. Between 1875 and 1913, average tariffs crept up in most European countries, with the notable exception of that bastion of free trade, Great Britain. Germany imposed the 1879 "Bismark" tariff on manufactured goods, and such tariffs ratcheted up 
elsewhere as well. Tariffs on agricultural goods also rose across Europe as a result of the railroad-induced "great grain invasion" of the 1870s. By the outbreak of World War I, average tariffs were in the 20 percent range across many countries. As O'Rourke and Williamson (1999, p. 29) note, "all the commodity market integration in the Atlantic economy after the 1860 s was due to the fall in transport costs between markets, and none was due to more liberal trade policy."

In 1950 these barriers were still in the 20 percent range, but had been supplemented by quantitative restrictions, exchange controls, and currency restrictions that had their origin in the interwar period. Multilateral trade negotiations, conduced under the auspices of the General Agreement on Tariffs and Trade (GATT), helped to reduce average tariffs to under 5 percent. Import quotas and exchange controls that persisted into the early post-war period were also phased out or eliminated. Furthermore, whole geographic areas have become, if not pure freetrade zones, at least zero tariff areas. The European Economic Community, founded in 1958, eliminated tariffs on member countries' trade and formed a customs union which has sought even closer economic ties as the European Union (EU). The North American Free Trade Agreement (NAFTA) expanded the U.S.-Canada Free Trade Agreement to include Mexico and, it is contemplated, other countries in central and south America. Though the merits of regional and preferential trade agreements vis-a-vis multilateral trade negotiations is controversial, both in terms of potential welfare effects and trade liberalization strategy, political efforts to eliminate trade barriers have undoubtedly contributed to deeper economic integration than experienced a century ago.

As is well known, however, even as tariffs have fallen, other measures have been adopted to protect domestic producers from import competition. Antidumping actions, voluntary restraint 
agreements, and other forms of protectionism persist and are not adequately reflected in these tariff measures. (Being selective and elastic in their implementation, these forms of protection can at times be worse than set tariffs.) In addition, large pockets of international trade, notably agricultural goods and textiles and apparel, have evaded efforts toward trade liberalization (at least until the Uruguay Round). These caveats prevent us from making definitive statements about the comparability of trade barriers now and a century ago. But they do not prevent us from suggesting that, broadly speaking, trade barriers have fallen substantially in the post-war period and today are quite likely lower than a century ago.

Informational Barriers to Exchange. In addition to transportation costs and trade barriers, informational barriers to exchange can limit the extent of market integration. Consumers are likely to have better information about the attributes of goods produced locally, while producers are likely to have better information about local tastes and demands. A century ago, before the age of mass communications, the difficulty of transmitting and receiving information about these attributes was plausibly greater than today.

To an extent, of course, these informational barriers to exchange could be overcome through network mechanisms. The high level of migration, including reverse and seasonal migration, that characterized the late $19^{\text {th }}$ century was an important channel for the flow of such information. Italian workers who traveled to the New World for a few years, or even just for the planting and harvest seasons, before returning to their home town in Italy formed an obvious network for information about supplies and demands in the Americas. ${ }^{14}$ Multinational

\footnotetext{
${ }^{14}$ Rauch and Casella (1998) distinguish between homogenous commodity goods in which organized exchanges (markets) set international reference prices and differentiated manufactured goods in which information networks appear to be important. Rauch (1999) presents evidence
} 
corporations similarly established (in their case, proprietary) networks for conveying such information across borders. ${ }^{15}$ But the presence of these mitigating factors does not change the conclusion that information relevant to product-market outcomes was more difficult to transmit and receive from abroad prior to $1913 .{ }^{16}$

Since multinationals were not as prevalent a century ago, their recent rise has acted to overcome reputational and informational barriers to trade. This points up an important contrast with a century ago. As alluded to in our introduction, recent observers have recalled the late nineteenth century as being a time of common values and institutions. Colonialization forced other countries in the world to adopt legal systems and commercial codes that, in some sense,

that search barriers to trade are higher for differentiated than for homogeneous products. He finds that proximity, a common language, and colonial ties are more important for matching international buyers and sellers and promoting trade in differentiated products than for goods traded on organized exchanges. This evidence is consistent with extra-market informational advantages or long-standing ties as being an important component of trade.

${ }^{15}$ Rangan and Lawrence (1999) argue that multinationals that pursue cross-border exchanges have advantages regarding the informationally-intensive activities of search (identifying potential exchange partners) and deliberation (assessing their reliability and trustworthiness). They find that the response of multinationals to real exchange rate changes is larger and more rapid than by non-multinationals. This result is consistent with the informational advantage view of such entities, and is inconsistent with the view that intra-firm transactions are less sensitive to market changes because of hierarchy or command issues.

${ }^{16}$ Of course, cross-border transactions can be impeded not just by informational problems but by (non-trade) policy-based reasons as well. Anderson and Marcouiller (1999) use survey measures of the security of economic transactions to determine the extent to which these factors impinge on international trade. They find that bilateral trade is significantly higher between countries whose government economic policies are impartial and transparent and whose legal systems are effective in enforcing commercial contracts. Indeed, they conclude that the insufficiency of these domestic institutions pose a greater constraint to international trade than tariff barriers, perhaps explaining the "home bias" in trade patterns. Developed countries may trade largely with one another because they have a comparable institutional base that secures property rights and commercial transactions. 
provided for harmonized economic policies across countries; indeed Rauch (1999), among others, has found that countries with colonial ties continue to trade unusually highly with one another long after independence has been established. As former colonies have regained their sovereignty, they have chosen to implement their own systems, which may account for their attenuated commercial links to developed countries.

The globalization of production has not forced such a convergence of domestic policies and institutions, but it has promoted greater integration. Could this intimacy potentially breed friction and conflict rather than accord and harmony?

\section{Containing Trade Tensions}

As trade expanded in the years leading up to World War I, aggrieved interests sought redress. Jeffrey Williamson (1998) argues that this "globalization backlash" manifested itself in increased political pressure to raise trade barriers, halt immigration, and stifle capital flows. Could the current wave of globalization generate similar pressures to retreat from the global economy? Or do we now have institutional safeguards that can relieve such anti-globalization pressures and preserve political support for an open world economy?

While the extent of the globalization backlash prior to 1913 should not be exaggerated, there was continual pressure in the United States to restrict immigration starting in the 1880s, and protectionist pressure throughout the industrializing world, especially in the period 1880-1895. By no stretch of the imagination was the open international system on the verge of collapsing upon itself by 1914, but pressure to restrict trade and immigration was more intense than today. We suggest three reasons why trade tensions were greater despite the fact that the extent of 
product-market integration was, if anything, less.

Macroeconomic Performance. First, macroeconomic performance -- both growth and stability -- is important to maintaining support for an open trade regime, and cyclical instability was, by most measures, more of a problem. Up to the outbreak of World War I, protectionist pressures were most pronounced during the "Great Depression" of the 1870s when cheap grain from the United States and Russia caused distress among European farmers and slower growth prompted manufacturers (even in Britain) to demand higher tariffs. This was well before greater integration that had emerged by the end of the century. Indeed, in the 15 years or so preceding the outbreak of war, there was little resurgence of protectionism. One factor that contributed to this outcome was the worldwide economic boom from the mid-1890s up to World War I.

For the developed economies in general, the postwar period has been one of economic expansion and cyclical stability. Such an environment is conducive to efforts at trade liberalization. The lesson is trite but true: while global integration undoubtedly creates sectoral pressures, those pressures are muted in an environment of steady economic growth and low unemployment. This explains why Congress, the focal point for constituent trade policy complaints, has been relatively quiet in the mid- and late-1990s compared with its trade activism of the early 1980s, when the United States experienced the deepest recession since the 1930s and the current account deficit began to soar. Indeed, Pat Buchanan's presidential candidacy based on “economic nationalism" resonated with voters in 1992 as memories of the early 1990s recession lingered, but fizzled in 1996 and (one expects) in 2000.

Social Insurance. Second, there were few forms of social insurance in place a century ago to mitigate the effects of surges in import competition. Unemployment insurance and 
adjustment assistance did not exist. Workers seeking compensation from foreign competition thus had no choice but to lobby Congress for higher tariffs. Congress was sympathetic to such pleas, although it could not always accommodate them quickly due to the political coordination costs of passing tariff legislation. ${ }^{17}$

To be sure, limited insurance mechanisms did exist. As Feldman (1993) notes, many late nineteenth century U.S. tariffs (particularly for iron and steel products and textiles and apparel) were set higher than necessary to ensure effective autarky (a phenomena known as "putting water in the tariff"). Redundant tariffs arise not for insurance reasons in Feldman's particular framework, but the insurance motive clearly could play a role in creating demands for high tariffs in the absence of other institutional mechanisms to provide temporary protection in the face of negative import price shocks. ${ }^{18}$

Moreover, the particular tariff form adopted, namely specific duties, provided another form of insurance. The ad valorem equivalent of specific duties - a particular dollar amount charged per imported quantity — is inversely related to the price of imports. Thus, if import prices fell as a result of some technological innovation (railroads bringing new sources of supply into the market, for example) or other development, the ad valorem tariff equivalent would automatically rise without requiring government action. This insured domestic producers and the

${ }^{17}$ Congress revised the tariff code only every seven years or so, on average, during the 1869-1913 period. Such legislation was only enacted when the House, Senate, and Executive were controlled by the same political party. Only on rare occasions would a tariff be passed on individual items in the absence of general legislation.

${ }^{18}$ In the context of an endogenous political economy model, Feldman shows that even riskneutral producers will seek redundant tariffs if import prices are stochastic. 
political system against pressure for higher tariffs in the face of trade-related distress. ${ }^{19}$

When the United States shifted away from this system, an even more extensive insurance mechanism was created to provide a safety valve for distressed industries. The Reciprocal Trade Agreements Act of 1934, which delegated tariff negotiating powers to the president, also included provisions for an "escape clause" from any obligation to have lower tariffs. This escape clause was not something that emerged gradually in response to increasing foreign competition but was instituted at the outset. The RTAA stated that the negotiated tariff reductions should not bring undue harm to domestic producers. The implicit provision to avoid injury to domestic producers was made explicit in the 1942 trade agreement with Mexico and formalized shortly thereafter in the events leading up to U.S. participation in the General Agreement on Tariffs and Trade (GATT). When protectionist elements in the Republican party sought to halt the Geneva GATT negotiations in early 1947, the Truman administration issued an executive order requiring an escape clause to be included in all future trade agreements. It allowed the United States to withdraw or modify tariff concessions "if, as a result of unforseen developments and of the concession granted by the United States on any article in the trade agreement, such article is being imported in such increased quantities and under such conditions as to cause, or threaten, serious injury to domestic producers of like or similar product..."

The executive order placated Congressional concerns and allowed the United States to complete the GATT negotiations. And at U.S. insistence, the escape clause was included as Article XIX of the GATT. Congress later feared that the escape clause was not being effectively

\footnotetext{
${ }^{19}$ An alternative explanation for the use of specific duties is that, with stable prices under the gold standard, there was no need to bother with the extra complexity of ad valorem tariffs, which also encouraged under invoicing.
} 
enforced and made a statutory provision for it in the Trade Agreements Extension Act of 1951.

The escape clause was supplemented with trade adjustment assistance to displaced workers in

1962. The Article XIX escape clause in the original GATT 1947 has continued without change in the GATT 1994 text with the end of the Uruguay Round and the establishment of the World Trade Organization.

While the leading interpretation of the escape clause is that it is a necessary political compromise to obtain greater support for trade agreements, others have thought that these are merely protectionist "loopholes." Expressing skepticism about the "safety valve" hypothesis, Sykes (1991, p. 273-4) argues that the "likelihood of direct protectionist legislation also decreases if such legislation violates international obligations and results in international sanction" and that "the ability of Congress to resist special interest pressures for protection, therefore, would likely be greater in the absence of Article XIX." The counter argument is that of Dam (1970, p. 99), who suggests that "the presence [of Article XIX] encourages cautious countries to enter into a greater number of tariff bindings than would otherwise be the case." ${ }^{20}$

${ }^{20}$ Hoekman and Kostecki (1995, p. 161) write that "Safeguard provisions are often critical to the existence and operation of trade-liberalizing agreements, as they function as both insurance mechanisms and safety-valves. The provide governments with the means to renege on specific liberalization commitments - subject to certain conditions - should the need for this arise (safety valve). Without them governments may refrain from signing an agreement that reduces protection substantially (insurance motive)." There is also Sykes's claim that the escape clause is protectionist because "the administrative route simply affords a device for some groups that lack the ability to mobilize the legislature to obtain protection . . . . any interest group with the political muscle to obtain protection through the legislative route seem unlikely to settle for a lesser level of protection through the administrative route." In the late $1950 \mathrm{~s}$, for example, the U.S. cotton textile industry did not bother with the escape clause procedure because it had the political clout to obtain a negotiated voluntary restraint agreement. Conversely, the automobile industry sought and obtained a voluntary export restraint with Japan in the early 1980s after having been denied escape clause remedies in 1979. 
Clearly, the challenge for policymakers operating in an era of greater economic integration is one of balance - making safeguards available, but without compromising open markets. As Lawrence and Litan (1986, p. 79) point out, "if the standards for obtaining import-related remedies are too restrictive, the escape clause mechanism cannot serve as an effective shock absorber for protectionist pressures. On the other hand, if the eligibility criteria are too weak, any domestic industry that faces import competition may become eligible for temporary protection." They called for adjusting the escape clause and trade adjustment assistance policies as a result of the trade frictions of the early 1980s, and their proposals may need to be dusted off in the future if globalization leads to a resurgence of such pressures.

Thus, the existence of escape clause provisions have been necessary to maintain political support for an open world trading system. The experience of the 1980s demonstrates that such measures, including voluntary restraint agreements in autos and steel, can in fact be temporary and may help to deflect protectionist measures that, under different institutional circumstances, could leave a more permanent imprint. Fischer and Prusa (1999) show that the combination of low general tariffs accompanied by the availability of safeguards is superior to uniform tariffs (the nineteenth century method) as insurance mechanisms. These exceptions are an integral part of the liberal trading system today. If macroeconomic stability can be sustained, then globalization and current methods of channeling protectionist pressures may be able to coexist.

The Growth of Countervailing Interests. Finally, while increased integration can threaten the economic interests of certain aggrieved groups, it also creates countervailing groups whose interests are enhanced. As noted above, much of the increased trade in recent years has been in intermediate goods. While domestic intermediate goods producers may be harmed by 
lower import prices, the competitive position of other domestic producers may depend upon those lower prices. In recent years, steel-using firms have successfully fought off efforts by the integrated steel producers to obtain extended protection, and semiconductor-using firms have successfully fought off efforts by semiconductor producers to obtain protection. Direct investments and international diversification by domestic producers in such sectors as automobiles has also muted national pressures for protection against foreign competition.

Given the greater trade integration that exists today compared to a century ago, one might have anticipated that much stronger protectionist pressures would be evident. That they are not suggests that stable macroeconomic management, the existence of escape clauses, and the rise of pro-trade economic interests have been capable of sustaining political support for an open trading system.

\section{Financial Integration Then and Now}

The typical "back to the future" story about capital markets before 1913 emphasizes the magnitude of net flows from the core countries of Western Europe to peripheral Europe and the overseas regions of recent European settlement. ${ }^{21}$ These flows were large relative to GDP indeed, larger than today — suggesting high levels of financial integration a hundred years ago.

At the same time, the range of sectors and activities to which this foreign investment was directed was narrower than today. For investment as for trade, the volume was large but the range of

\footnotetext{
${ }^{21}$ Financial integration was no new phenomenon, of course. Neal (1990) documents the extent of financial integration within Europe itself over the two preceding centuries. Breizas (1995) argues that foreign lending played an important role in financing the British industrial revolution, while Zevin (1992) emphasizes the growth of lending by Europe to the United States, Latin American and the British colonies in the first half of the $19^{\text {th }}$ century.
} 
affected activities was small.

The net capital outflow ranged as high as 9 per cent of GDP on an annual average basis for Britain and scaled comparable peaks, at least briefly, in France, Germany and the Netherlands. ${ }^{22}$ Current account deficits exceeded 10 per cent of GDP in Australia, Canada and Argentina for significant portions of the three decades preceding 1913 and sometimes exceeded 5 per cent of GDP in Finland, Norway and Sweden. (For comparison, recall that Thailand's “dangerously large" current account deficit in 1996 was eight per cent of GDP.) Regressionbased studies on a larger sample of countries, designed to deal with sample-selection bias, find lower savings-investment correlations before 1945 than today, reinforcing the conclusion that capital flows were large relative to savings, investment and GNP. ${ }^{23}$ Current account surpluses and deficits were also more persistent prior to 1914 than in recent decades. ${ }^{24}$

Fishlow (1985) summarizes the conventional wisdom on this subject as follows. In the overseas regions of recent settlement to which the bulk of European lending flowed, external resources were invested in infrastructure projects which enhanced the borrowing country's capacity to export. Foreign funds were used to construct port facilities, railway networks and other "internal improvements." At the same time, the lending countries (particularly Britain) provided open markets for the raw materials and agricultural commodities produced and exported

${ }^{22}$ See Bairoch and Kozul-Wright (1996) for estimates for these and other countries. For comparison, note that Japan and Germany's current account surpluses in the 1980s never exceeded five per cent of GDP.

${ }^{23}$ See for example Bayoumi (1990), Eichengreen (1990) and Taylor (1996). Price-based studies paint the same picture.

${ }^{24}$ As measured by the Phillips-Perron $\mathrm{Z}$ statistic. This is true for surplus and deficit countries alike. 
by these newly settled regions. ${ }^{25}$ In this way, foreign borrowing generated a stream of export revenues sufficient to service and repay the borrowed funds.

Upon scrutinizing it more closely, one discovers several blemishes on this smoothlycomplexioned history. For one thing, infrastructure investment was not always productive, a point that any observer of the Thai economy in the 1990s would be quick to appreciate. For more than a few countries, the story of railway investment in the late-19th century was a story of fraud, bankruptcy and debt default. ${ }^{26}$ Nor were railway enterprises and other companies supplying infrastructure services the only borrowers. Governments too had voracious appetites for external finance. A non-negligible share of public spending took the form of subsidies for the construction of railways and infrastructure projects, but governments which borrowed abroad typically did so, as Fishlow emphasizes, not to finance public investment but to underwrite public consumption. ${ }^{27}$ And financial crises and sharp reversals in the direction of capital flows, culminating in debt default, were anything but rare, as we describe below.

What is clear is that foreign borrowing meant almost exclusively borrowing by railways and borrowing by governments. Consider the composition of pre-1914 portfolio investment by

${ }^{25}$ Note that even for the United States, the most industrialized of the regions of recent overseas European settlement, commodity exports (gold, silver and agricultural commodities, and later petroleum) were the dominant source of export revenues throughout this period (Wright 1990).

${ }^{26}$ Some of these tales are told in Eichengreen (1996).

${ }^{27}$ The Egyptian government's spending on the services of "ballet dancers, etc." springs to mind. 
Great Britain, the leading creditor country of the period. ${ }^{28}$ Early estimates suggest that fully 40 per cent of British overseas investments in quoted securities were in railways, 30 per cent were in the issues of governments (national, state and municipal), 10 per cent were in resource-extracting industries (mainly mining), and 5 per cent were in public utilities. ${ }^{29}$ Note that portfolio investment in commercial, industrial and financial activities is absent from this list. Six out of every seven pounds sterling of portfolio investment was in securities of debtors with relatively tangible, transparent assets (the ability to tax in the case of governments, trunk and branch lines and rolling stock with a well-defined revenue-raising capacity in the case of railways, mineral reserves in the case of mining companies). Davis and Gallman (1999), focusing on the " $19^{\text {th }}$ century emerging markets," finding that nine of every ten pounds of British investment in Argentina, Australia, Canada and U.S. between 1865 and 1890 went into railroads and government bonds. ${ }^{30}$

Data for portfolio capital flows to emerging markets in the 1990s paint a different picture. We have tabulated these by recipient sector for both bank lending and bonds from Capital Data's

${ }^{28}$ British investors held approximately 40 per cent of the stock of long-term foreign investments outstanding in 1913, and there is no reason to think that the composition of British investment is unrepresentative in terms of its concentration in the railway and public sectors. Fishlow (1995) suggests that French and German foreign investment may have been more heavily directed toward governments and less toward railways, but this does not undermine our central point.

${ }^{29}$ See e.g. Royal Institute for International Affairs 1937.

${ }^{30}$ According to their estimates, the fraction ranges from 86 per cent in Australia to 92 per cent in Canada (Davis and Gallman, 1999, p.7). Davis and Huttenback (1986) provide comparisons with domestic investment in quoted securities. Their Chart 2.8 confirms the picture of a pattern of overseas portfolio investment concentrated in agricultural and extractive activities (especially in the Empire), in transportation, and in public utilities. Domestic portfolio investment, in contrast, was disproportionately concentrated in manufacturing and in the commercial and financial sectors. 
Bankware and Bondware, respectively. Admittedly, one way of reading these figures is "the more things change, the more they remain the same." But to many readers they will suggest the growing importance of lending to the financial-services sector (banks, etc.), to enterprises producing commercial services, and to manufacturing. The kind of statement made by Madden (1985, p.73) with reference to the late $19^{\text {th }}$ century, that "British investment in [U.S.] banks...and industry was of little importance in this period," would scarcely be made of portfolio investment in emerging markets today.

Less information exists on the volume of short-term capital flows prior to 1914, but everything we know points to a lower level than today, even adjusting for the smaller size of the world economy. Bloomfield's (1963) discussion suggests that short-term flows were significantly smaller than long-term flows, in sharp contrast to today: Bank for International Settlements data on turnover in foreign exchange markets suggest that gross flows are in the range of $\$ 1.25$ trillion a day, or more than $\$ 250$ trillion a year, much larger than corresponding figures for long-term capital flows.

\section{Why is Financial Integration Greater Today?}

These differences in the scope of market integration were consequences of information asymmetries, contracting problems, and macroeconomic risks that limited the extent of capital and commodity flows prior to 1913 and that continue to limit them, albeit to a lesser extent, today. By information problems we mean the difficulty of determining product, project, and borrower quality. By contracting problems we mean difficulties of detecting fraud and of attaching collateral. By macroeconomic risks we mean mainly exchange risk. We now characterize the 
nature of these information, contracting and macroeconomic limits to market integration and describe how they were attenuated over time. Of particular interest is our discussion of whether market discipline sufficed to remedy these obstacles to the development of smoothly-functioning international markets, or whether official intervention was also required. As noted above, the focus is on capital flows from Britain to the United States.

Information Problems. Any discussion of information flows must start with the communications technology of the day. The transatlantic cable was laid in the 1860 s, coming into operation in 1866. Prior to its opening, it could take as long as three weeks for information to travel from New York to London. ${ }^{31}$ With the inauguration of the cable, this delay dropped to one day. By 1914 the time for cable transmission was down to less than a minute. Garbade and Silber (1978) compare the London and New York prices of US bonds four months before and four months after the cable and find a significant decline in the mean absolute difference. There is every reason to think that the cable had a comparable impact on other markets. ${ }^{32}$

The radio telephone was the next breakthrough. Like the telegraph, it first linked the national financial center (London or New York) to the hinterlands and regional exchanges before linking up those centers internationally (linking Europe with North America by 1900).

It should be apparent why this information and communications technology translated into a smaller volume of short-term capital flows. Today currency traders respond almost instantaneously to minute-to-minute changes in currency values. Prior to 1870 , when it might take weeks for this information to cross the Atlantic, and even after the advent of the cable and

\footnotetext{
${ }^{31}$ Garbade and Silber (1978), p.826.

${ }^{32}$ The cable reached Buenos Aires in 1878 and Tokyo in 1900.
} 
the radio telephone, news arrived at longer intervals.

Long-term lending to manufacturing, commercial and financial concerns was deterred not so much by the limitations of the communications technology as by the difficulty of assembling and evaluating the information to be communicated. Lenders were reluctant to lend because of the difficulty of distinguishing good and bad credit risks. This information asymmetry created adverse selection (where the average credit quality of the pool of borrowers declines with increases in the interest rate) and therefore credit rationing. Overseas investors were further deterred by the difficulty of monitoring and controlling management's actions ex post — of detecting malfeasance and rent dissipation and preventing owner-managers whose downside risk was truncated by limited liability from devoting borrowed funds to riskier projects.

We now offer some evidence about the structure of late-19th century financial markets consistent with this emphasis on asymmetric information as a barrier to more broadly-based foreign investment. ${ }^{33}$ Several already-noted characteristics of late-19th century international capital markets are explicable in terms of obstacles to information flows. For example, asymmetric information can explain the disproportionate share of railway bonds in foreign investment portfolios. To be sure, information asymmetries were not the only factor contributing to disproportionate importance of railway securities. America's transcontinental railways were built only once, in this period. Private as well as social returns on railway investment were attractive (Fogel 1964). But the manufacturing, financial and commercial sectors of the economy were growing every bit as fast as transportation, and foreign investment in these sectors was less; information asymmetries explain this fact. It was relatively easy to monitor the actions of a

\footnotetext{
${ }^{33}$ We then go on to account for this impacted information environment itself.
} 
railway company's management: investors could verify how much track had been laid, where it had been laid, and how much traffic it carried more easily than they could verify and evaluate the investment decisions of managers of concerns in these other sectors. ${ }^{34}$ These considerations explain the particular preference of British investors for "coal roads," that is, railways whose traffic was disproportionately comprised of coal haulage, since this made it relatively straightforward to forecast operating revenues.

Obstacles to the flow of information can also explain the disproportionate importance of debt as opposed to equity in foreign investment portfolios (Baskin 1988), since debt reduces the risk to investors when imperfect information creates agency problems. The pattern persists today (see e.g. Eichengreen and Mody, 1998), but a century ago it was if anything more pronounced. ${ }^{35}$

Information asymmetries can explain the disproportionate importance of family groups (the foreign branches of the Rothschild and Morgan families, for example) and of the merchant and investment banks that grew out of them, which underwrote foreign bond issues and served as conduits for foreign investment, acting as delegated monitors and emitting signals of borrower credit worthiness. ${ }^{36}$ They can explain the well-known "Kuznets cycle pattern" in which

\footnotetext{
${ }^{34}$ This is not to say that there were not other important problems, as we shall see below, of evaluating management's actions even in the railway sector.

${ }^{35}$ The 1997 issue of the World Bank's Global Development Finance suggests that stocks and bonds are now of roughly equal importance in international portfolio capital flows to emerging markets, after a long period in which debt instruments (bonds and bank loans) dominated purchases of equities.

${ }^{36}$ The dependence of information flows on group and family ties raises the same issues in capital as well as commodity markets. As Rauch and Casella (1998) emphasize, and we explain in Section 2 above, such ties can give rise to "trade diversion" as well as "trade creation," and whether they result in a more or less efficient global allocation of resources is an open question.
} 
immigration and financial capital tended to flow in the same direction (what Hatton and Williamson 1992 refer to as the tendency for capital to chase after labor), as the migrants provided the European sending countries with valuable information about local conditions. They can explain the "sovereign credit rating departments" established by intermediaries like Credit Lyonnais (Flandreau 1998). They can explain the development of investment trusts (the $19^{\text {th }}$ century analog of modern mutual funds), to whom investors delegated information-gathering and analysis functions. They can explain the explosive growth of insurance companies, investments in which were attractive to households partly because they could offer an attractive rate of return as a result of their comparative advantage in gathering information from far-flung regions (Snowden 1995). They can explain the popularity of specialized publications like The Investor's Monthly Manual, Burdett's Stock Exchange Official Intelligence, Poor's Manual of Railroads, and Herapath's Railway Journal. They can explain the practice by established railroads of guaranteeing the bonds of feeder lines.

Finally, information asymmetries can explain the surprisingly limited importance of FDI prior to 1914 and the importance of the free standing company as the vehicle for foreign direct investment. A considerable majority of foreign investment prior to 1914 took the form of portfolio investment, whereas direct investment and portfolio investment are of roughly equal importance today. ${ }^{37}$ And whereas $19^{\text {th }}$ century FDI was undertaken mainly by free-standing companies (companies incorporated in Britain, France, Belgium and other Western European countries for the sole purpose of investing and doing business in an emerging market), it takes place today through the agency of multinational enterprises that establish foreign branches and

\footnotetext{
${ }^{37}$ Bloomfield (1968), pp.3-4.
} 
foreign subsidiaries. ${ }^{38}$ Free standing companies, in the words of Wilkins (1998, p.13), "were structured to solve the problem posed earlier; business abroad was risky; it was hard to obtain adequate and reliable information about firms in distant lands; returns were unpredictable; but there were clearly opportunities abroad; a company organized within the source-of-capital country, with a responsible board of directors, under source-of-capital country law, to mobilize capital(and other assets) and to conduct the business in foreign countries could take advantage of the opportunities, while reducing the transaction costs by providing a familiar conduit."

In part, these information problems can be understood in terms of sheer physical and cultural distance. The anecdote about the dinner in London at which a British investor, encountering an American guest, inquired whether Cincinnati or Ohio was the larger city may be apocryphal but the story has a point: lack of familiarity with the regions that the railways were penetrating was an impediment to capital flows. Madden (1985, p.317) notes that while some two-thirds of all American railroad bonds issued publicly between 1860 and 1880 were for what he calls "developing" and "underdeveloped" (as opposed to already developed) parts of the country, only one-third of those purchased by British investors were for those regions. ${ }^{39}$

Contracting Problems. Information problems were, in our view, the key explanation for the relatively limited scope of late-19th century capital flows. But they were not the entire story.

${ }^{38}$ See Wilkins (1998). Free standing companies became increasingly important as British investors gradually diversified beyond investments in railroads and government bonds into farming, ranching, mining and brewing and they sought to surmount the agency problems associated with the attempt to control far-distant American management. See below.

${ }^{39}$ Madden's developed regions were New England and the North East, his developing regions the East Central and South, and his underdeveloped regions the North Central, Central and Far West. 
Beyond the immediate problem of geographical ignorance, distance made for problems of control. It was hard to monitor actions taken by management thousands of miles away when round-trip communication could take a month. The case of the Atlantic \& Great Western Railway, which filed for bankruptcy in 1867 , illustrates the consequences. Its filing revealed that management had issued an additional $\$ 75$ million of securities to continue operating in the face of mounting losses, thereby diluting the claims of existing creditors without the knowledge of the latter. ${ }^{40}$ It is said that this experience had a significant effect in discouraging British investors from taking positions in other American railroads.

Foreign investors were also deterred by the uncertain legal security of their claims. Because the United States was a federation, corporations were chartered by the states, not the federal government, and governed by the laws of the state in question. Madden $(1985, \mathrm{p} .231)$ reports that many of these laws "allowed railroad managers far more latitude in issuing securities and disposing of railroad earnings than did British law." States prohibited foreigners from serving as directors of the corporations chartered there. In response, some British investors hired American citizens to represent them on the board, but this extra layer between ownership and control had the predictable effect of adding principal-agent slack.

Foreign investors also had reason to fear that they would not be treated fairly under American bankruptcy law. They worried that companies might be wound up and their assets sold off to other claimants to the detriment of foreign investors. ${ }^{41}$ Thus, America's experience before 1914 points up the importance for emerging markets seeking to attract foreign investment of

\footnotetext{
${ }^{40}$ Oberholtzer (1907), vol 2, p.104.

${ }^{41}$ For details, again see Madden (1985), p.231 and chapter 4.
} 
transparent and equitable bankruptcy laws. This of course was the attraction of investing in the colonies, where bankruptcy law was familiar and creditor rights were relatively secure. Direct investment through free standing companies was another solution. Wilkins, in the preceding quote, emphasizes not only the difficulty of obtaining "adequate and reliable information" but also the advantages of establishing the country doing business abroad under "source-of-capital country law" to minimize contracting problems. British shareholders could be confident of their rights because the free standing company was subject to British law.

Macroeconomic Risks. A number of observers emphasize exchange risk, unstable and uncertain monetary and fiscal policies, and political risk as factors limiting pre-1913 international investment flows. Madden (1985, p.255) emphasizes the importance of a stable standard of value, stating that it is "of course common knowledge" that British investors viewed securities issued by countries not on the gold standard as riskier than those of countries that were. Many foreign securities issued in London were denominated in sterling and specified that principal and interest were payable in sterling (or in foreign currency convertible into sterling at a fixed rate of exchange), but in this case exchange rate fluctuations created credit risk instead of currency risk. (Currency depreciation might push the borrower into bankruptcy by raising the value of his debt service payments relative to his income stream. ${ }^{42}$ ) In the case of government bonds, the fear was that governments off gold would succumb to the temptation to live beyond their means. For example, Baring's had unusual difficulty in placing U.S. government bonds in the second half of

\footnotetext{
${ }^{42}$ This phenomenon will be familiar to observers of the Asian crisis. There, banks which were prohibited from maintaining open foreign positions and which therefore offset their foreigncurrency liabilities by making foreign-currency loans to domestic corporations simply substituted credit risk for currency risk.
} 
the 1860s, since investors feared that profligacy of the government operating under a fiat money regime would precipitate a financial crisis and force it to repudiate the debt. The Bland Bill of 1877, which raised the specter of large-scale silver coinage, similarly caused British investors to liquidate their U.S. government securities in favor of colonial bonds with interest and principal guaranteed in sterling. Again in the early 1890s, the possibility of free silver coinage led foreign investors to liquidate their holdings of U.S. securities and to a rise in the premia on U.S. bonds and foreign exchange. Bordo and Rockoff (1996) find that the effect was general: loans to countries with a fluctuating standard of value commanded significantly higher interest rates.

The Absence of Adequate Accounting Standards. While difficulties of contract enforcement and macroeconomic risks were significant deterrents to foreign investment, we have argued that asymmetric information was the overwhelming important obstacle to international capital flows. And these information problems were compounded by the inadequacy of prevailing auditing and accounting standards. The point then-Deputy Treasury Secretary Lawrence Summers has made about US domestic financial transactions -- "If one were writing a history of the American capital market I would suggest to you that the single most important innovation shaping that capital market was the idea of generally accepted accounting principles" — applies to the country's international financial transactions as well. ${ }^{43}$ In particular, British investors were deterred from investing in the United States by the underdevelopment of American accounting practices.

Summers's suggestion begs the question of why those accounting practices remained underdeveloped for so long and what led to the emergence of "generally accepted accounting

${ }^{43}$ Summers (1999), p.7. 
principles." Was it market discipline — the reluctance of markets to lend to a country where such principles were not followed? Or was regulatory intervention required to overcome free-rider and lemons problems and to ensure that appropriate practices were followed?

In fact, both market discipline and regulatory intervention were needed for the adoption of generally-accepted accounting principles. Market discipline was applied by British investors, who insisted on the transfer to the United States of accounting practices accepted in Britain. (Their preferred agent for the transfer, as we shall see, was the British chartered accountancy firm.) Another source of market discipline was the New York Stock Exchange, which from the turn of the century required the publication of standardized balance sheets by all entities whose securities were accepted for listing.

But market discipline was not enough. In addition there was the need for regulatory intervention, starting with the Interstate Commerce Commission, which required the railroads it regulated to provide information using standardized accounting practices from the $1880 \mathrm{~s}$, and culminating in the regulations imposed by the Securities and Exchange Commission in 1933.

Standardized accounting practices emerged first in Britain because the industrial revolution started there. Prior to industrialization, "public accountancy in Britain had been considered a marginal occupation not ranking in status with medicine, law or theology.",44 Accountants also audited, the distinction between the auditor's inspective function and the accountant's analytical function only emerging in the $20^{\text {th }}$ century. While a commercial partnership might employ an accountant to post and adjust a ledger, search for fraud and defalcation, and prepare a rudimentary financial statement, only with the emergence of limited

${ }^{44}$ Miranti (1990), p.30. 
liability and large-scale manufacturing did there develop a demand for more systematic accounting services. The emergence of the capital-intensive manufacturing enterprise required management to develop information control systems to effectively oversee the company's various operations and monitor the flow of funds (Chandler 1990). ${ }^{45}$ The adoption of modern financial accounting methods was a way, in other words, of securing a competitive advantage.

The use of auditing and accounting principles and the employment of individuals specializing in their use first became prominent in the railways, where scale was exceptional and scheduling, coordination, and delegation were of the essence. Not incidentally, Chandler characterizes the railways as the first enterprises to make use of extensive managerial hierarchies and the multidivisional form. The consolidation of separate manufacturing concerns by figures like Andrew Carnegie in the 1870s and 1880s and the merger movement of the 1890s accelerated the spread of information management and control systems from the transportation to the

${ }^{45}$ In addition, in Britain, as in the U.S. (see below), public policy played a role. The Companies Acts of 1844, 1856 and 1862 required concerns selling shares to the public to provide certain information to shareholders, which in turn encouraged management to hire accountants to discharge this obligation. They required dividends to be paid out of earnings, not out of capital, prompting boards of directors to engage accountants to vouch for their adherence to this distinction. The Companies Act of 1844, adopted in response to the financial frauds of the early $19^{\text {th }}$ century, originated the modern concepts of mandatory corporate and prospectus disclosure. It required registered companies to issue an annual report containing a balanced sheet audited by an independent auditor responsible to the shareholder. To be sure, these provisions did not work perfectly. They did not specify, for example, how recent the balance sheet information had to be, leading some firms to publish the same information year after year. Nor did the 1844 Act specify the duties of the auditor. Only toward the end of the century were these loopholes finally eliminated. Nonetheless, better securities-market regulation is plausibly the best explanation for Britain's rapid overtaking of the US in terms of the depth, breadth and sophistication of its securities markets. 
manufacturing sector. ${ }^{46}$ Interestingly, many contemporaries predicted that the large corporations created in this period would fail because "no one person or board of directors could successfully master such large organizations..." ${ }^{47}$ The use of modern auditing, accounting and information systems was to prove them wrong. ${ }^{48}$

But this is to get ahead of the story. The accounting practices of most $19^{\text {th }}$ century enterprises were rudimentary. Even relatively sophisticated enterprises like the Remington Arms Company did not account for depreciation in their financial statements. Indeed, the concept was unknown: companies generally treated outlays on plant and equipment as current rather than depreciable expenses.

As noted, the railroads played a key role in transforming this state of affairs. They were the first enterprises to make systematic use of the concepts of working capital and flow of funds. While their operation was relatively transparent to foreign investors, they also provided strikingly little information to their shareholders. Many railroads provided no annual reports until the 1890s. ${ }^{49}$ The exceptions generally did so on a voluntary and unaudited basis. As the Railroad

${ }^{46}$ In America, the modern integrated industrial concerned developed out of the post-Civil War railroad merger movement, which demonstrated the ability of larger concerns to provide goods and services at lower prices. Railroads, followed by oil, steel, tobacco, sugar and coal companies, were organized as trusts. That is, a separate corporation would be established in each state in which it operated, and the trust would serve as the corporation of corporations. (The term "money trust" is indicative of the spread of this corporate form to the financial-services sector.) See Lamoreaux (1985).

${ }^{47}$ Previts and Merino (1998), p.128.

${ }^{48}$ Thus, Carnegie employed a large staff in his cost department and attributed his financial success partly to his ability to keep track of his various enterprises' expenditures.

${ }^{49}$ In response to a query from the New York Stock Exchange, the Delaware, Lackawana and Western Railroad wrote that it "makes no report [and] publishes no statements" (Sobel, 1965, 
Gazette put it in 1893, "The annual report of a railroad is often a very blind document and the average shareholder taking one of these reports generally gives up before he begins."50

British investors, burned by unethical promoters, increasingly demanded as a condition for lending that railways issue regular financial statements prepared by British chartered accountants. British accountants set up practice in America from the mid-19th century, as British accounting firms found it less expensive to hire resident British accountants than to send London-based accountants on short-term visits. These firms gradually hired additional staff of British-born naturalized Americans and -- horrors -- even native-born Americans. These British accountants in turn played a key role in the formation of the American Association of Public Accountants, which promoted the adoption of standardized methods and accountancy training.

What was standard practice for railways gradually became standard practice in other sectors. The role of British accountants is evident in the "brewers boom" of the 1880 s, for example, when British capital was attracted to newly-established breweries in such far-flung locations as St. Louis, Milwaukee, Denver and San Francisco. Since distance complicated the tasks of monitoring management and ascertaining local market conditions, British investors demanded financial statements prepared by British chartered accountants. British accounting firms responded by opening regional offices to provide information on American companies in these fast-expanding regions. Price Waterhouse and Company opened offices in Chicago in 1891, Broads, Patterson in 1894. Investment banking firms such as J.P. Morgan and Company and Kuhn Loeb and Company selected these British accountancy firms to audit the financial

p.85).

${ }^{50}$ Quoted in Previts and Merino (1979), p.81. 
statements included in the prospectuses for securities floated on the London market. ${ }^{51}$

Thus, foreign investors played a key role in the transfer of British accounting principles to the emerging markets of North America, and international accounting firms were key agents in transferring the technology. In the same way that emerging markets today can import internationally-accepted auditing and accounting standards by contracting with internationallyrecognized auditing and accounting firms, U.S. companies issuing foreign securities in the late $19^{\text {th }}$ century imported those standards by contracting for the services of British chartered accounting firms. None of this guaranteed financial transparency or uniform auditing and accounting standards, but it created pressure in that direction.

Market self-regulation in the form of the disclosure requirements of the New York Stock Exchange created pressure to move in the same direction. From the 1860s the Exchange attempted to require disclosure and reporting by companies listing shares for trading. These provisions were strengthened in 1899. But enforceability remained a chronic problem. The U.S. equity market was too decentralized; there existed too many regional exchanges for the New York Exchange to run the risk of eroding its market position by delisting powerful clients. As Sylla and Smith (1995, p.197) put it, "when companies demurred from observing the Exchange's requirements or flouted them, the rules were bent to keep them from going away."

Thus, market discipline alone does not appear to have sufficed to deliver standardized accounting practices. In addition, there was a role for government. The "Populist revolt" of the 1880s centered on railroad freight rates and on whether the railways were colluding to the

${ }^{51}$ As Miranti (1990, p.34) observes, "The certificate of a well-known accounting firm was thought to improve the marketability of American securities among European investors." 
detriment of farmers dependent on their services. It led in 1887 to the creation of the Interstate Commerce Commission (ICC) to regulate rates. One of the key provisions of the Interstate Commerce Act required carriers to submit regular reports, on which the ICC based its determinations. But whether freight rates were disproportionate to the railroads' operating costs was an accounting question, and different railways accounted for costs in different ways. The lack of a uniform accounting standard thus impeded the ICC's early operation. A key step was thus when the commission established a uniform accounting standard for railroads in 1894 . Since the ICC released the financial reports submitted by the railroads to the public, its standard became a focal point for investors seeking to encourage the establishment of uniform practices.

A second important step was when New York State intervened in a dispute between two rival practitioner groups, the American Association of Public Accountants and the New York Institute of Accountants. Throughout the 1880s, the AAPA and NYIA had competed to control the new profession, promoting rival accounting standards. They had submitted a series of rival bills to the New York State Senate in the 1890s proposing a uniform state examination and a three-man examining board for certifying professional competency and limiting the use of the title “certified public accountant." The NYIA's version was adopted in 1896. State certification thus did much to accelerate the emergence of a uniform accounting standard.

By 1905 eight other states had followed New York in establishing state licensing laws which required candidates for certification to pass a written exam or appear before an examining board. It remained to transform these state standards into a uniform national accountancy standard. This was facilitated by inclusion in the 1903 Illinois licensing law of a reciprocity clause which granted licenses to practitioners licensed in other jurisdictions provided that their home 
states extended the same privilege to Illinois practitioners. Other states followed suit. ${ }^{52}$

Two interwar developments sealed the emergence of standardized accounting principles. One was the advent of the corporate and individual income tax. For obvious reasons, the corporate tax did much to encourage the acceptance of accounting practices like depreciation. Those practices were standardized in the 1920s, when the Internal Revenue Service demanded and obtained the prompt resolution by the courts of accounting issues affecting its operations. The other catalytic event was the collapse of the stock market in 1929. The Crash, thought by some to have been precipitated by the collapse of Krueger and Toll, whose head Ivar Krueger had deceived the public about his companies' financial condition, convinced many observers that inadequate public information was a factor in the volatility of asset markets. ${ }^{53}$ New Deal legislation signed into law on May 27, 1933 therefore required all companies issuing publiclytraded securities to file financial statements certified by independent public accountants. The Securities Act of 1934 (the Securities Exchange Act) then mandated the filing of annual audited financial statements for all companies whose investment securities had been previously issued to the public. Reaching agreement between federal authorities and certified public accountants on what constituted acceptable accounting practice would take time, but the SEC legislation provided strong impetus for the development of a uniform standard.

${ }^{52}$ In addition, the Federation of State Societies of Pubic Accounts, established in 1902, promoted the harmonization of CPA licensing across states.

${ }^{53}$ It will be recalled that Berle and Means' influential book on the separation of ownership and control in the modern corporation stressed the need for more objective financial information to ensure the efficient functioning of financial markets (Berle and Means 1932). Miranti (1990) argues that this book had an important influence on the public-policy debate leading ultimately to the creation of the Securities and Exchange Commission. 
Thus, the United States' own experience suggests that the development of a uniform, transparent accounting standard is no mean task. It suggests that market discipline and government intervention are both needed to yield the desired result. International investors can be an important source of that market discipline, and international accounting firms can be efficient agents of technology transfer. But until that transfer is effected, the integration of the domestic financial markets with their foreign counterparts will necessarily remain incomplete.

\section{Section 6. Financial Crises}

The Victorian age of capital flows to emerging economies, like our era, was marred by banking and currency problems and abrupt reversals of capital flows. The important questions are what caused these events and how serious their economic consequences were.

Background. The classic pattern with resonance for today is Latin America's experience of three lending booms and busts between 1820 and 1914. ${ }^{54}$ The first wave of British capital flows to the new states of the region to finance infrastructure and gold and silver mines ended with the crisis of 1825. British investors had purchased Latin American stocks and bonds, some of which were in nonexistent companies and even countries, with gay abandon (Neal 1992). The boom ended with a stock market crash and a banking panic. The new countries defaulted on their debts and were barred from international capital markets for several decades until they renegotiated terms and began paying into arrears (Cole, Dow and English 1995).

\footnotetext{
${ }^{54}$ See Marichal (1989). A fourth wave occurred in the 1920's after the mantle of leadership in international financial affairs shifted from London to New York. (Bordo, Edelstein and Rockoff 1999). It ended at the end of the decade with the collapse of commodity prices and the Great Depression. Virtually all countries, with the principal exception of Argentina, defaulted on their debt. Private capital did not return to the region for four decades.
} 
The second wave was in the 1850's and 1860's to finance Latin American railroads and ended with the 1873 financial crisis in Europe. Again faced with deteriorating terms of trade, many countries defaulted on their debts. The third wave in the 1880's involved massive flows from Britain and European generally to finance the interior development of Argentina and Uruguay; it ended with a crash in 1890 and the insolvency of Barings, the famous London merchant bank. Argentine state bonds went into default, a moratorium was declared, and capital flows to the region dried up for half a decade.

Although Latin experience is the classic, the United States was also the subject of lending booms. The first wave of British capital in the 1820's and 1830's went to finance canals and the cotton boom. It ended in the depression of 1837-1843 with the defaults by eight states, and British investors shunned the U.S. for the rest of the decade. The second wave followed the Civil War and was used to finance westward expansion. The threat that the U.S. would abandon gold for silver precipitated capital flight in the mid-1890's but unlike the Latin case the crisis of 1895 did not lead to the suspension of convertibility or to an extended reversal of capital flows. ${ }^{55}$

Financial crises in this period were precipitated by events in both lending and the borrowing countries. A number of crises began in Europe due to the real shocks of harvest failures. On several such occasions $(1837,1847,1857)$ the Bank of England, in response to an “external drain” which depleted its gold reserves, raised its discount rate. This tightened

${ }^{55}$ Australia, the third of the four big recipients of British capital, the fourth being Canada, also went through a significant boom-bust cycle. A land boom in the 1880 's, partly financed by British capital turned to bust with a turnaround in the terms of trade in 1890. This led to massive bank insolvencies in 1893, because the Australian banks, unlike their counterparts in Canada, ignored their "real bills" statutes and lent on the collateral of land. British depositors, burned by their losses, remained wary of Australia for more than a decade (Davis and Gallman 1999). 
conditions in the domestic money market, sometimes causing bank failures, and had serious consequences for capital flows to the New World. Thus, the 1837 crisis spread to North America via British intermediaries that had been financing the export of cotton from New Orleans to Liverpool, leading to the suspension of specie convertibility and to widespread bank failures in the United States.

Not all crises originated in the Old World. In Latin America they were often precipitated by supply shocks which made it impossible for commodity-exporting countries to service their debts and by the expansionary monetary and fiscal policies adopted in an effort to protect the economy from the consequences. They could also be triggered by banking instability, especially in the U.S., a country hobbled by a fragile unit banking system and the absence of a lender of last resort.

Crises in the periphery spread to the European core and back through the linkages described in Section 4. Classic examples are the Baring Crisis of 1890, the 1893 crisis in the U.S., Italy and Australia, and the 1907 crisis in the United States and Europe (Goodhart and DeLargy 1999).

While there are similarities between the "emerging-market crises" of the Victorian Age and recent events, a key difference is the monetary regime. The earlier crises occurred under the fixed exchange rates of the gold standard, while the recent crises occurred in a regime of managed flexibility. ${ }^{56}$ This has several important consequences. First, whereas the gold standard quickly

${ }^{56}$ To be sure, this last label covers a multitude of different exchange-rate regimes (some would say a multitude of sins), but the essential point is that, Hong Kong and Argentina to the contrary notwithstanding, exchange rates were less firmly pegged during the recent crisis than they had been at the periphery of the Atlantic Economy a hundred years earlier. 
transmitted crises between peripheral and core countries, today the advanced countries are better insulated from shocks at the periphery. Central banks and governments in the advanced-industrial countries now have more room for maneuver, not being constrained by a commitment to defend the nominal price of gold. One might say that Alan Greenspan in 1998 should have been thankful that policy makers had not bought into an earlier Alan Greenspan's arguments favoring the gold standard!

Second, and working in the other direction, credible adherence to the gold standard -- in the sense that maintaining the gold parity would be the primary policy goal and, if it had to be abandoned in the face of a war or other emergency, it would be restored at the original parity -ensured that capital flows would be stabilizing once resolution was underway (Eichengreen 1992, Miller 1996, 1998, Bordo and Kydland 1995). This was the case for the core countries, the advanced countries of Western Europe, the U.S. (with the exception of the free silver era in the mid 1890's) and the British Dominions, but not necessarily for other peripheral countries with poor records of fiscal probity and dubious credibility.

Another key difference affecting the resolution of crises is that the peripheral countries neither possessed domestic lenders of last resort nor were the beneficiaries of international rescue loans. Well before 1914 the core countries had developed reasonably effective lenders of last resort and an ad hoc system of international financial cooperation (Bordo and Schwartz 1998, Eichengreen 1992). But the same was not true at the periphery, and countries there suffered the consequences. Today the problem at the periphery is different. There is a domestic safety net in most emerging countries so that banking panics are transformed into situations where the liabilities of an insolvent banking system are taken over by the government. This in turn can 
convert a banking crisis into a currency crisis (Dooley 1998).

Evidence on the Severity and Longevity of Crises. To compare the severity and longevity of crises, we examine changes in the annual rate of growth of real GDP. We calculate the growth rate and assess its behavior before, during and after crises for 15 "emerging markets" in the period $1880-1914 .^{57}$ We then make similar calculations for 10 well-known emerging countries (Argentina, Brazil, Chile, Indonesia, Korea, Malaysia, Mexico, Philippines, Singapore and Thailand) that have experienced crises in the past 25 years.

We identify currency and banking crises from a survey of the historical literature. ${ }^{58}$ For an episode to qualify as a banking crisis, we must observe either bank runs, bank failures and the suspension of convertibility of deposits into currency (a banking panic), or else significant banking-sector problems (including failures) that are resolved by a fiscally-underwritten bank restructuring. ${ }^{59}$ For an episode to qualify as a currency crisis, we must observe a forced change in

${ }^{57}$ The countries are those used in Bordo and Schwartz (1996a): Argentina, Australia, Brazil, Canada, Chile, Denmark, Finland, Greece, Italy, Japan, Norway, Portugal, Spain, Sweden, United States. Our criteria for classifying a country as emerging are (i) whether it was primarily a recipient of capital flows and (ii) its level of per capita income. Thus, in the pre-1914 era a number of the 20th century's most advanced countries (the U.S., Japan, and the Scandinavians) are classified as emerging markets. A similar comparison is made by DeLargy and Goodhart (1999). Their empirical base is more limited, however; they concentrate on the behavior of a number of famous crisis episodes in the pre 1914 era in 5 emerging countries: the U.S., Australia, Argentina, Italy and Austria, with similar evidence for victims of the recent Asian crisis. An alternative metric would measure the wealth losses associated with the resolution of the crises. This is the approach taken by Caprio and Klingbiel (1996). By this metric the losses associated with banking crises in the 1980's and 1990's is likely to be larger than before 1914 (Calomiris 1999). 1999).

${ }^{58}$ The resulting chronology is presented in a companion paper (Bordo and Eichengreen

\footnotetext{
${ }^{59}$ This allows us to distinguish between liquidity crises before 1914 in which lender of last resort intervention was either absent or unsuccessful, and more recent events where a lender of
} 
parity, the abandonment of a pegged exchange rate, or an international rescue. An alternative measure of currency crises that we also use is an index of exchange market pressure (EMP), calculated as a weighted average of the percentage change in the exchange rate with respect to the core country (the UK before 1914, the U.S. thereafter), the change in the short-term interest rate differential with respect to the core country, and the difference of the percentage change in reserves of a given country and the percentage change in reserves of the core country. ${ }^{60} \mathrm{We}$ count an episode as a currency crisis when it shows up as positive according to either or both of these indicators.

Table 5 presents averages for the individual country episode in the pre-1914 era and the recent period. ${ }^{61}$ For each country we calculate the growth rate in the crisis year relative to the five-year-average growth rate preceding the crisis; the growth rate in the crisis year relative to the three-year-average growth rate preceding the crisis; the difference between the crisis-year growth rate and the preceding year's growth rate; the difference between growth the year following the crisis and the crisis-year growth rate; the difference between the three-year-average growth rate following the crisis and the crisis-year growth rate; and finally the difference between the fiveyear-average growth rate following the crisis and the crisis-year growth rate. Assuming that the economy is at its trend growth rate five years before the crisis, this gives a rough measure of the

last resort or deposit insurance is in place and the main problem has been bank insolvency. In fact, however, a number of banking crises which occurred in Europe before 1914 did not involve panics and in this respect were not dissimilar from episodes occurring more recently.

${ }^{60}$ This builds on the exchange-market-pressure model of Girton and Roper (1977), following the methodology in Eichengreen, Rose and Wyplosz (1995, 1996).

${ }^{61}$ The individual cases are tabulated and described in Bordo and Eichengreen (1999). 
extent to which growth deviated from trend and then recovered. ${ }^{62}$

A key fact emerging from Table 5 is that while banking and financial crises with serious recessionary effects are no new phenomena, those output effects were on average somewhat less serious before 1914 compared to today. This holds for banking crises, currency crises and twin crises alike. Thus, while output declined by 3 per cent relative to trend in the average post-1972 crisis, the comparable number for the pre-1914 period was only 2 per cent. The contrast is especially sharp for crises with both banking and currency components, which have been exceptionally disruptive since 1972 (when the average drop in output was 5 per cent) but were less so prior to 1913 (when that drop was "only" 2 per cent).

Relative to these averages, the drop in output in the recent Asian crises was especially steep: Korea's growth rate declined seven percentage points below its pre-crisis five-year-average growth rate, eight percentage points below its three year pre-crisis average and seven percentage points from the year preceding the crisis. Indonesia's performance was similar, while Thailand's was the worst (at minus $13,13,11 \%$ respectively). ${ }^{63}$

How does this compare with the worst of the pre-1914 era? In fact, the two most

${ }^{62}$ To illustrate, this generates the following picture for the U.S. around the crisis of 1893. 1893. Real GDP dropped 5\% in the crisis year, declined relative to the average of the preceding 5 years by $9 \%$, declined relative to the average of the preceding 3 years by $12 \%$, and declined relative to the year before the crisis by $14 \%$. In the 3 years following the crisis, growth increased on average to $2 \%$, so the deviation of the crisis year from the 3 year average that we calculate is $7 \%$. Finally, in the 5 years following the crisis, growth recovered by $9 \%$ relative to the crisis. Thus it took the U.S. five years to return to its pre-crisis growth rate.

${ }^{63}$ In contrast to the Asian cases, real GDP declined only modestly in the Mexican crisis of 1994 with output only declining by $1 \%$ below its five year average during the crisis year, less than $1 \%$ below its three year average and $2 \%$ in the crisis year. It recovered $3 \%$ a year after the crisis and $4 \%$ after three years. 
infamous pre-World War I episodes, the U.S. in 1893 and Argentina in 1890, were even worse than Asia in recent years. For the U.S., growth during the crisis years declined by nine percentage points relative to its previous five-year average, 12 percentage points below its three-year average, and 14 percentage points from the pre-crisis year. However, the growth rate recovered to its pre-crisis level within 5 years. For Argentina the numbers are dramatic: minus 17\%, 20\%, $24 \%$, with recovery in growth not complete after 5 years. Clearly, generalizations about the pre1914 period should be drawn cautiously, since that period appears to have featured a small number of exceptionally severe crises along with a larger number of milder episodes. ${ }^{64}$

Generalizing about the post-crisis recovery is even more difficult. On the one hand, the recovery from currency crises is quicker prior to 1914 . Then, growth rose by 2 percentage points between the crisis year and the three years following, whereas since 1972 there has been essentially no post-crisis recovery until after 3 years. The recovery from currency crises both began earlier and continued more rapidly prior to 1914. DeLargy and Goodhart find a similar pattern and interpret it in terms of the resumption rule. Prior to 1914, countries driven off the gold standard generally intended to restore convertibility at the previously-prevailing exchange rate once the crisis passed. While investors who held domestic-currency-denominated assets suffered losses when the currency collapsed, they anticipated gains as the currency recovered to

${ }^{64}$ Another reason for caution is that the results change when we include the crises that erupted in 1914 due to the outbreak of World War I. These are numerous; including them increases the size of our sample by about half. They are also relatively severe, since the disruption to international financial relations due to the outbreak of the war was extensive. Including these episodes in the averages makes the immediate post-crisis drop in output slightly more severe prior to 1915 than after 1972. While there is good reason to regard these wartime shocks as special (and for therefore not including them in the comparison with our day), this is another reminder of the difficulty of generalizing about financial stability in the last age of globalization. 
its traditional parity. To put the point another way, there was little reason to fear that abandonment of the currency peg would unleash uncontrolled inflation, since the authorities were committed to reestablishing the previous rate of exchange. Hence, devaluation did not unleash persistent capital flight. Rather, gold and capital began flowing back in at a relatively early date, stabilizing the economy and stimulating recovery.

In contrast, the recovery from banking crises starts earlier in the modern period, in the first post-crisis year as opposed to the second or third post-crisis year. This is true whether or not banking crises are accompanied by currency crises. A likely explanation is the absence of an effective lender of last resort at the periphery in the pre-1914 era to quickly restore depositor confidence, stabilize supplies of money and credit, and sustain the provision of intermediation services. The U.S. crises of 1893 and 1907, which were greatly aggravated by the absence of effective last-resort lending (leading in turn to the establishment of the Fed), clearly make this point. One can argue that regulatory forbearance and central bank bailouts have adverse longterm effects by weakening market discipline and leading to a less efficient allocation of capital. Indeed, there is some suggestion of this in the data: while recovery from banking crises is initiated earlier in the post-1972 period, the subsequent expansion accelerates less dramatically and is sustained less successfully, as if market discipline and the efficiency with which credit is allocated are less (than in comparable episodes a hundred years ago).

Automatic stabilizers were also absent prior to 1914. Some recent commentators (e.g. Krugman 1998) have noted that the Asian crisis countries (and other emerging markets) found their use of automatic stabilizers constrained by a lack of confidence and the existence of high capital mobility. That may be true, but the comparison suggests that they still have been able to 
adopt a more concerted response than their counterparts a century ago. Other commentators have been critical of regulators for failing to force through an earlier resolution of banking problems. Again, they have a point, but the striking fact is that recovery from banking crises has tended to begin earlier in the recent period than in the typical crisis episode a hundred years ago. A final point is that there were no international rescue packages available to emerging economies prior to 1914 , whereas such rescues are a prominent feature of the international financial landscape today. ${ }^{65}$ Some would argue these international rescue operations may have themselves contributed to the severity of recent crises by aggravating the problems of moral hazard accompanying the provision of a safety net, but it is also possible that international efforts to encourage the quick resolution of banking crises and to provide resources for recapitalization have contributed to the earlier initiation of recovery from banking crises.

Thus, while the crisis problem is hardly new, there are some new and distinctive features of recent crises. The drop in output following their outbreak is even more dramatic. And for currency crises, the subsequent recovery is slower. In this respect as others, there are aspects of our current age of globalization that are both unprecedented and disturbing.

\section{Section 7. Conclusion}

While presenting a good deal of detail, we have sought in this paper to emphasize a small number of general points. First, the globalization of commodity and financial markets is historically unprecedented. Facile comparisons with the late nineteenth century notwithstanding,

\footnotetext{
${ }^{65}$ The Belmont-Morgan loan arranged for the U.S. Treasury in the 1890 s being a prominent exception.
} 
the international integration of capital and commodity markets goes further and runs deeper than ever before.

Second, that the advent of highly integrated commodity and financial markets has been accompanied by trade tensions and problems of financial instability should not come as a surprise, for the earlier period of commodity- and financial-market integration that is our basis for comparison was also marked by trade tensions and financial instability. The surprise is that these problems are not even more severe today, given that the extent of commodity- and financialmarket integration is so much greater.

Accounting for this surprise is the agenda for research. One possibility is the stabilizing role of the institutions built in the interim. At the national level this means social and financial safety nets. At the international level it means the WTO, the IMF, the Basle Committee of Banking Supervisors. These institutions may be far from perfect, but they are better than nothing, judging from the historical correlation between the level of integration on the one hand and the level of trade conflict and financial instability on the other. The financial safety net may create moral hazard, but it at least prevents financial catastrophe. Contingent protection may prevent the full gains from trade from being realized, but it at least sustains a critical mass of political support for open markets. Global markets without global governance may create problems, but these multilateral institutions would appear to provide at least an imperfect substitute for some of the functions of the latter, or so outcomes would suggest.

The other explanation for the contrast is that the simple maturation of markets over time has made it easier to live with globalization. The development of better auditing and accounting practices at the national level has made it easier to apply those same practices to international 
transactions, with stabilizing consequences. The development of futures markets on which producers can hedge their exposure to world prices has made it easier for them to live with global markets that deliver outcomes beyond their control. These processes were already underway in the $19^{\text {th }}$ century (Williams 1986 ), but they have since developed considerably further.

Lest we be accused of being Panglossian, we should emphasize that current problems of trade conflict and financial instability are real and pressing, especially for smaller, more open, lower-income countries with the least ability to protect themselves from the consequences. Governments seeking to make the world safe for global capitalism still have a ways to go. 
Figure 1

\section{U.S. Merchandise Trade as Percent of GNP} 1869 - 1997

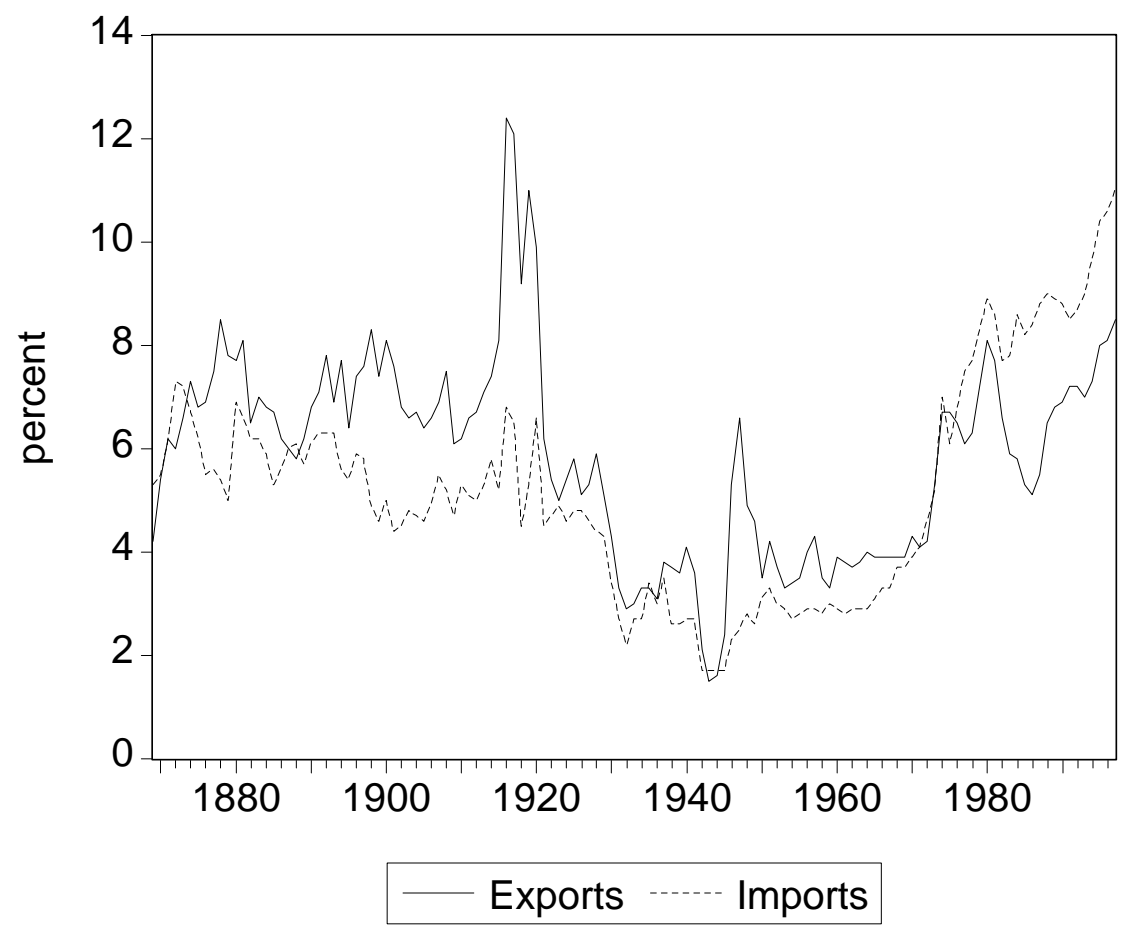


Figure 2

\section{Trade in the U.S. Economy}

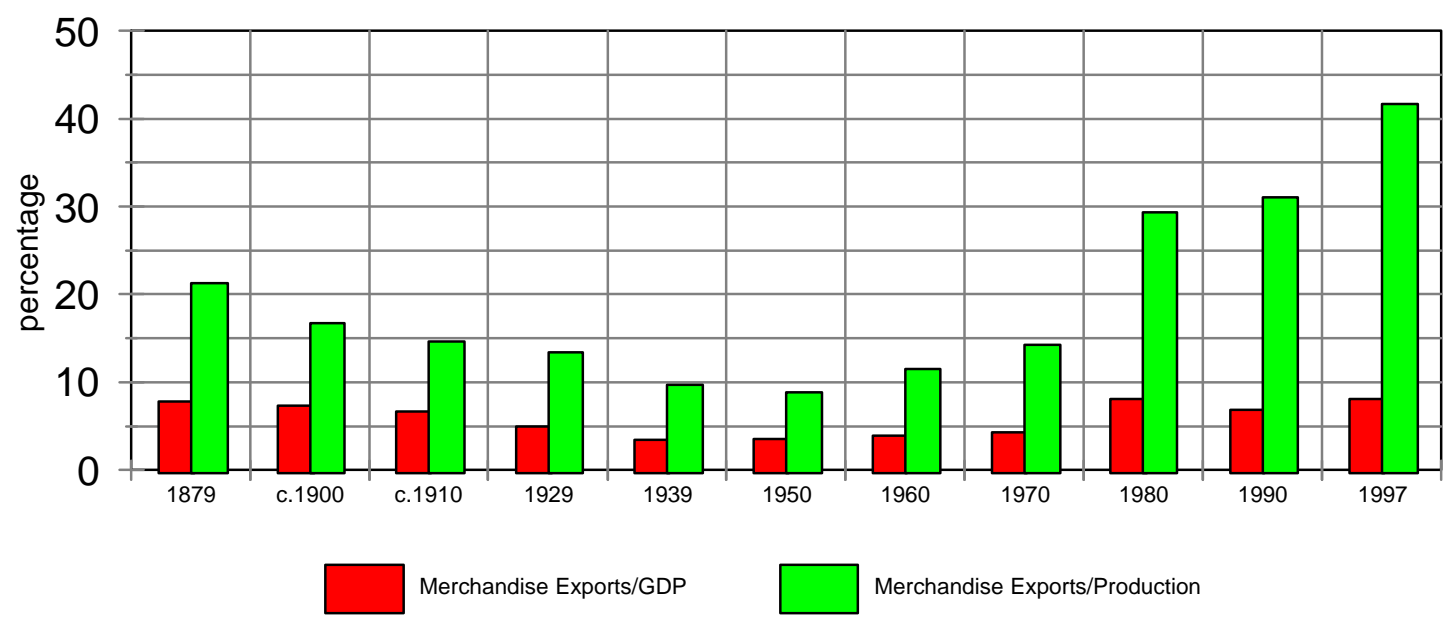


Table 1: Trade as a Percentage Share of Domestic Output/Consumption, 1909 and 1993 A. Exports as Share of Domestic Shipments

\begin{tabular}{|l|c|c|}
\hline & 1909 & 1993 \\
\hline Corn & 2 & 31 \\
\hline Wheat & 20 & 63 \\
\hline Cotton & 65 & 35 \\
\hline Coal & 4 & 16 \\
\hline Raw Tobacco & 29 & 46 \\
\hline Tobacco Manufactures & 1 & 17 \\
\hline Chemicals & 16 & 15 \\
\hline Motor Vehicles \& Parts & 2 & 9 \\
\hline $\begin{array}{l}\text { Fabricated Metal } \\
\text { Products }\end{array}$ & 7 & 31 \\
\hline $\begin{array}{l}\text { Non-Electrical } \\
\text { Machinery }\end{array}$ & 5 & 21 \\
\hline Electrical Machinery & 3 & 21 \\
\hline Instruments & 5 & \\
\hline
\end{tabular}

B. Imports as a Share of New Supply (Domestic Output and Imports)

\begin{tabular}{|l|c|c|}
\hline & 1909 & 1993 \\
\hline Wool & 45 & 73 \\
\hline Textiles \& Apparel & $7^{\mathrm{a}}$ & 35 \\
\hline Leather & 3 & 57 \\
\hline Chemicals & $12^{\mathrm{a}}$ & 9 \\
\hline Motor Vehicles \& Parts & 1 & 25 \\
\hline $\begin{array}{l}\text { Fabricated Metal } \\
\text { Products }\end{array}$ & 1 & 8 \\
\hline $\begin{array}{l}\text { Non-Electrical } \\
\text { Machinery }\end{array}$ & $<1$ & 25 \\
\hline Electrical Machinery & $<1$ & 27 \\
\hline Instruments & $<1$ & 16 \\
\hline
\end{tabular}

Sources: For 1909, Department of Commerce, Statistical Abstract of the United States, 1913. For 1993, U.S. Bureau of the Census (1995). ${ }^{\text {a }}$ From Lipsey (1999). 
Table 2: U.S. Foreign Direct Investment, Selected Years (as percent of U.S. GNP)

\begin{tabular}{|l|c|c|}
\hline & $\begin{array}{c}\text { U.S. Direct } \\
\text { Investment Abroad }\end{array}$ & $\begin{array}{c}\text { Foreign Direct } \\
\text { Investment in the } \\
\text { United States }\end{array}$ \\
\hline 1914 & $\approx 7$ & $\approx 3-4$ \\
\hline $1929 / 30$ & $\approx 7$ & $\approx 1$ \\
\hline 1960 & 6 & 1 \\
\hline $\begin{array}{l}1996 \\
\text { Market Value }\end{array}$ & 20 & 16 \\
\hline
\end{tabular}

Sources: For 1914, Wilkins (1970), p. 201 and Wilkins (1989), p. 699. For 1929/30 and 1960, series U 26-39. For 1996, Survey of Current Business, July 1998, p. xx, available at http://www.bea.doc.gov/bea/ 
Table 3: Average Tariffs on Imported Manufactured Goods

\begin{tabular}{|l|c|c|c|c|c|c|}
\hline & 1875 & 1913 & 1931 & 1950 & $\begin{array}{c}\text { Pre- } \\
\text { Uruguay } \\
\text { Round }\end{array}$ & $\begin{array}{c}\text { Post- } \\
\text { Uruguay } \\
\text { Round }\end{array}$ \\
\hline France & $12-15$ & 20 & 30 & 18 & -- & -- \\
\hline Germany & $4-6$ & 17 & 21 & 26 & -- & -- \\
\hline Italy & $8-10$ & 18 & 46 & 25 & -- & -- \\
\hline $\begin{array}{l}\text { United } \\
\text { Kingdom }\end{array}$ & 0 & 0 & n.a. & 23 & -- & -- \\
\hline $\begin{array}{l}\text { European } \\
\text { Union }\end{array}$ & -- & -- & -- & -- & 5.7 & 3.6 \\
\hline Canada & n.a. & 26 & n.a. & & 9.0 & 4.8 \\
\hline United States & $40-50$ & 44 & 48 & 14 & 4.6 & 3.0 \\
\hline
\end{tabular}

Source: Bairoch (1993), and Schott (1994) for last two columns. 
Table 4

\begin{tabular}{|lcccc|}
\hline \multicolumn{5}{|c|}{ Bank and Bond Market Lending to Emerging Markets } \\
\hline Functional Sectors & Number of Bonds Value of Bonds & Number of Loans & $\begin{array}{r}\text { Amount of Loans } \\
\text { (in US millions) }\end{array}$ \\
& 77 & 18155.85 & 147 & 24897.091 \\
\hline Central Bank & 368 & 128080.44 & 294 & 39121.941 \\
Other Government & 385 & 67695.01 & 879 & 110844.658 \\
Infrastructure Investment & 153 & 28047.07 & 315 & 56226.715 \\
$\quad$ oil/coal/gas & 107 & 21951.1 & 233 & 30414.017 \\
energy-utility & 125 & 17623.31 & 331 & 24203.918 \\
$\quad$ others & 10 & 664.04 & 87 & 10717.272 \\
Mining & 1302 & 161610.12 & 1769 & 132049.471 \\
Finance (banks, etc) & 415 & 38504.02 & 946 & 66996.553 \\
Manufacturing & 241 & 26261.95 & 867 & 76545.381 \\
Service & 3183 & 508592.91 & 5868 & 572017.017 \\
\hline \multicolumn{5}{r}{} \\
\hline
\end{tabular}

Source: see text. 
Table 5

Fluctuations in Annual Growth Rates Around the Time of Crises: Summary Statistics 1880-1998.

Part A: All Crises: means (number of crises)

\begin{tabular}{|l|c|c|c|}
\hline & $\mathbf{1 8 8 0 - 1 9 1 3}(\mathbf{2 2})$ & $\mathbf{1 9 7 3 - 1 9 9 8}(\mathbf{3 0})$ & Recent (7) \\
\hline $\mathrm{g}_{\text {crisis }}-\mathrm{g}_{(-5)}$ & 0.01 & -0.03 & -0.05 \\
\hline $\mathrm{g}_{\text {crisis }}-\mathrm{g}_{(-3)}$ & 0.00 & -0.03 & -0.06 \\
\hline $\mathrm{g}_{\text {crisis }}-\mathrm{g}_{(-1)}$ & -0.02 & -0.03 & -0.06 \\
\hline $\mathrm{g}_{(+1)}-\mathrm{g}_{\text {crisis }}$ & 0.00 & 0.02 & 0.01 \\
\hline $\mathrm{g}_{(+3)}-\mathrm{g}_{\text {crisis }}$ & 0.01 & 0.02 & 0.04 \\
\hline $\mathrm{g}_{(+5)}-\mathrm{g}_{\text {crisis }}$ & 0.01 & 0.03 & \\
\hline
\end{tabular}

Part B: Twin Crises: means (number of crises)

\begin{tabular}{|l|c|c|c|}
\hline & $\mathbf{1 8 8 0 - 1 9 1 3}(\mathbf{9})$ & $\mathbf{1 9 7 3 - 1 9 9 8}(\mathbf{1 4})$ & Recent (6) \\
\hline $\mathrm{g}_{\text {crisis }}-\mathrm{g}_{(-5)}$ & -0.02 & -0.05 & -0.05 \\
\hline $\mathrm{g}_{\text {crisis }}-\mathrm{g}_{(-3)}$ & -0.02 & -0.05 & -0.06 \\
\hline $\mathrm{g}_{\text {crisis }}-\mathrm{g}_{(-1)}$ & -0.02 & -0.05 & -0.06 \\
\hline $\mathrm{g}_{(+1)}-\mathrm{g}_{\text {crisis }}$ & 0.00 & 0.03 & -0.01 \\
\hline $\mathrm{g}_{(+3)}-\mathrm{g}_{\text {crisis }}$ & 0.01 & 0.05 & 0.04 \\
\hline $\mathrm{g}_{(+5)}-\mathrm{g}_{\text {crisis }}$ & 0.02 & 0.05 & \\
\hline
\end{tabular}


Part C: Banking Crises: means (number of crises)

\begin{tabular}{|l|c|c|l|}
\hline & $\mathbf{1 8 8 0 - 1 9 1 3}(\mathbf{8})$ & $\mathbf{1 9 7 3 - 1 9 9 8}(\mathbf{5})$ & Recent (0) \\
\hline $\mathrm{g}_{\text {crisi }}-\mathrm{g}_{(-5)}$ & -0.02 & -0.03 & \\
\hline $\mathrm{g}_{\text {crisis }}-\mathrm{g}_{(-3)}$ & -0.02 & -0.03 & \\
\hline $\mathrm{g}_{\text {crisis }}-\mathrm{g}_{(-1)}$ & -0.03 & -0.02 & \\
\hline $\mathrm{g}_{(+1)}-\mathrm{g}_{\text {crisis }}$ & -0.03 & 0.02 & \\
\hline $\mathrm{g}_{(+3)}-\mathrm{g}_{\text {crisis }}$ & 0.00 & 0.02 & \\
\hline $\mathrm{g}_{(+5)}-\mathrm{g}_{\text {crisis }}$ & 0.05 & 0.01 & \\
\hline
\end{tabular}

Part D: Currency Crises: means (number of crises)

\begin{tabular}{|l|c|c|c|}
\hline & $\mathbf{1 8 8 0 - 1 9 1 3}(\mathbf{5})$ & $\mathbf{1 9 7 3 - 1 9 9 8}(\mathbf{1 1})$ & Recent (1) \\
\hline $\mathrm{g}_{\text {crisis }}-\mathrm{g}_{(-5)}$ & 0.00 & -0.02 & -0.05 \\
\hline $\mathrm{g}_{\text {crisis }}-\mathrm{g}_{(-3)}$ & 0.03 & -0.01 & -0.05 \\
\hline $\mathrm{g}_{\text {crisis }}-\mathrm{g}_{(-1)}$ & -0.01 & 0.00 & -0.04 \\
\hline $\mathrm{g}_{(+1)}-\mathrm{g}_{\text {crisis }}$ & -0.03 & 0.01 & \\
\hline $\mathrm{g}_{(+3)}-\mathrm{g}_{\text {crisis }}$ & 0.02 & 0.00 & \\
\hline $\mathrm{g}_{(+5)}-\mathrm{g}_{\text {crisis }}$ & 0.00 & 0.01 & \\
\hline
\end{tabular}

Note: $g_{\text {crisis }}$ is the annual growth rate of real GDP at the crisis year. $g_{\left(\_\right)}$is the average annual growth rate of real GDP N years before of after the crisis.

Data Sources: Bordo and Schwartz (1996a), IFS CD-ROM (1999). 


\section{References}

Anderson, James E. and Douglas Marcouiller (1999). "Trade, Insecurity, and Home Bias: An Empirical Investigation.” NBER Working Paper 7000 (March).

Bairoch, Paul (1993), Economics and World History, Chicago: University of Chicago Press.

Bairoch, Paul and Richard Kozul-Wright (1998), "Globalization Myths: Some Reflections on Integration, Industrialization and Growth in the World Economy," In Transnational Corporations and the Global Economy, edited by Richard Kozul-Wright and Robert Rowthorn. New York: St. Martin's Press.

Baldwin, Richard E. and Philippe Martin (1999), “Two Waves of Globalization: Superficial Similarities, Fundamental Differences,” NBER Working Paper 6904 (January).

Baskin, Jonathan B. (1988), "The Development of Corporate Financial Markets in Britain and the United States, 1600-1914: Overcoming Asymmetric Information,” Business History Review 62, pp.197-237.

Bayoumi, Tamim (1990), "Saving-Investment Correlations: Immobile Capital, Government Policy, or Endogenous Behavior?” IMF Staff Papers 37, pp.360-387.

Berle, Adolf A. and Gardiner C. Means (1932), The Modern Corporation and Private Property, New York: Commerce Clearing House.

Bloomfield, Arthur I. (1968), Patterns of Fluctuation in International Finance Before 1914, Princeton Studies in International Finance no. 21, International Finance Section, Department of Economics, Princeton University.

Bordo, Michael and Barry Eichengreen (1999), "Plu Ca Change: A Century of Banking and Currency Crises," unpublished manuscript, Rutgers University and University of California, Berkeley.

Bordo, Michael D., Barry Eichengreen and Jongwoo Kim (1998), "Was There Really an Earlier Era of Financial Globalization Comparable to Today?" In Bank of Korea, The Implications of the Globalization of World Financial Markets, Seoul: Bank of Korea, pp.27-83.

Bordo, Michael D., Michael Edelstein, Hugh Rockoff (1999), "Was Adherence to the Gold Standard a 'Good Housekeeping Seal of Approval' During the Inter-War Period?" unpublished manuscript, Rutgers University (February).

Bordo, Michael D. and Hugh Rockoff (1996), "The Gold Standard as a Good Housekeeping Seal of Approval," Journal of Economic History 56, pp.389-428.

Bordo, Michael D. and Anna J. Schwartz (1996a), "The Operation of the Specie Standard: Evidence for Core and Peripheral Countries, 1880-1990" in Jorge Braga de Maceda, Barry Eichengreen and Jaime Reis (eds.), Currency Convertibility: The Gold Standard and Beyond, New York: Routledge, pp. 11-83. 
Bordo, Michael D. and Anna J. Schwartz (1998), "Under What Circumstances, Past and Present, Have International Rescues of Countries in Financial Distress Been Successful?" NBER Working Paper 6824 (December).

Breizas, Elise (1995), "Foreign Capital Flows in the Century of Britain's Industrial Revolution: New Estimates, Controlled Conjectures,” Economic History Review XLVIII, pp.46-67.

Calomiris, Charles (1999). "Victorian Perspectives on the Banking Collapse of the 1980's and 1990's." Columbia University (mimeo).

Chandler, Alfred D. (1990), Scale and Scope: The Dynamics of Industrial Capitalism, Cambridge, Mass.: Harvard University Press.

Cole, Harold L., James Dow and William B. English (1995), "Default, Settlement, and Signaling: Lending Resumption in a Reputational Model of Sovereign Debt," International Economic Review 36, pp. 365-385.

Collins, William J., Kevin H. O'Rourke, and Jeffrey Williamson (1997), “Were Trade and Factor Mobility Substitutes in History?" NBER Working Paper 6059 (June). Forthcoming in Trade and Factor Mobility, edited by xxx, NewYork: Cambridge University Press.

Council of Economic Advisers (1999), Economic Report of the President, Washington, DC: GPO.

Dam, Kenneth (1970), The GATT: Law and the International Economic Organization, Chicago: University of Chicago Press.

Davis, Lance E. and Robert Gallman (1999), "Waves, Tides, and Sandcastles: The Impact of Foreign Capital Flows on Evolving Financial Markets in the New World, 1865-1914," unpublished manuscript, Caltech and University of North Carolina, Chapel Hill.

Davis, Lance E. and Robert A. Huttenback (1986), Mammon and the Pursuit of Empire, Cambridge: Cambridge University Press.

Dooley, Michael P. (1997), "A Model of Currency Crises in Emerging Countries," NBER Working Paper.

Eichengreen, Barry (1990), "Trends and Cycles in Foreign Lending," in Horst Siebert (ed), Capital Flows in the World Economy, Tubingen: Mohr, pp.3-28.

Eichengreen, Barry (1992), Golden Fetters: The Gold Standard and the Great Depression, 1919-1939, New York: Oxford University Press.

Eichengreen, Barry (1996a), Globalizing Capital: A History of the International Monetary System, Princeton: Princeton University Press. 
Eichengreen, Barry (1996b), "Financing Infrastructure in Developing Countries: Lessons from the Railway Age," in Ashoka Mody (ed.), Infrastructure Delivery: Private Initiative and the Public Good, Washington, DC: The World Bank, pp.107-128.

Eichengreen, Barry and Ashoka Mody (1998), "What Explains the Changing Spreads on EmergingMarket Debt: Fundamentals or Market Sentiment?” NBER Working Paper No. 6408 (February).

Eichengreen, Barry, Andrew Rose and Charles Wyplosz (1995), "Exchange Market Mayhem: The Antecedents and Aftermath of Speculative Attacks," Economic Policy 21, pp. 249-312.

Eichengreen, Barry, Andrew Rose and Charles Wyplosz (1996), "Speculative Attacks on Pegged Exchange Rates: An Empirical Exploration with Special Reference to the European Monetary System" in Matthew Canzoneri, Wilfred Ethier and Vittorio Grilli (eds.), The New Transatlantic Economy, New York: Cambridge University Press.

Feenstra, Robert C. (1998) "Integration of Trade and Disintegration of Production in the Global Economy," Journal of Economic Perspectives 12, pp.31-50.

Feldman, David H. (1993), "Redundant Tariffs as Rational Endogenous Protection," Economic Inquiry 31, pp. 436-447.

Fishlow, Albert (1985), "Lessons from the Past: Capital Markets During the $19^{\text {th }}$ Century and the Interwar Period," in Miles Kahler, The Politics of International Debt, Ithaca, NY: Cornell University Press, pp.37-94.

Fischer, Ronald D., and Thomas J. Prusa (1999), “Contingent Protection as Better Insurance,” NBER Working Paper 6933 (February).

Flandreau, Marc (1998), “Caveat Emptor: Coping with Country Risk without the Multilaterals, 18701914,” CEPR Discussion paper 2004 (October).

Fogel, Robert (1964), Railroads and American Economic Growth, Baltimore: Johns Hopkins University Press.

Garbade, Kenneth D. and William L. Silber (1978), "Technology, Communication and the Performance of Financial Markets, 1840-1975," Journal of Finance 33, pp.819-832.

Girton, Lance and Donald Roper (1997), “A Monetary Model of Exchange Market Pressure Applied to Postwar Canadian Experience," American Economic Review 67, pp. 537-48.

Goldberg, Pinelopi K., and Frank Verboven (1998), “The Evolution of Price Discrimination in the European Car Market,” NBER Working Paper No. 6818 (November).

Goodhart, Charles and P.J.R. DeLargy (1999), "Financial Crises: Plus ça change, plus c'est la meme chose," LSE Financial Markets Group Special Paper No. 108. 
Gordon, Barry K. (1992), "Multivariate Cointegration Tests and the Law of One Price in International Wheat Markets," Review of Agricultural Economics 14 (June), pp.117-124.

Hatton, Timothy J. and Jeffrey G. Williamson (1992), "International Migration and World Development: A Historical Perspective," Harvard Institute of Economic Research Discussion Paper no. 1606 (August).

Hermalin, Benjamin E. and Andrew K. Rose (1999), "Risks to Lenders and Borrowers in International Capital Markets,” NBER Working Paper no. 6886 (January).

Hoekman, Bernard, and Michel Kostecki (1995), The Political Economy of the World Trading System: From GATT to WTO. New York: Oxford University Press.

Hummels, David (1999), "Transportation Costs and International Integration in Recent History," unpublished manuscript, University of Chicago.

Hummels, David, Dana Rapoport, and Kei-Mu Yi (1998), "Vertical Specialization and the Changing Nature of World Trade," Economic Policy Review, Federal Reserve Bank of New York (June), pp.79-94.

International Monetary Fund (1998), World Economic Outlook, Washington, D.C. (May).

Irwin, Douglas A. "The United States in a New Global Economy? A Century's Perspective," American Economic Review Papers and Proceedings 86 (May 1996), pp. 41-46.

Kindleberger, Charles P. (1973), The World in Depression 1929-1939, Berkeley: University of California Press.

Kindleberger, Charles P. (1989), Manias, Panics and Crashes: A History of Financial Crises, Revised Edition, New York: Basic Books.

Krugman, Paul (1995), “Growing World Trade: Causes and Consequences,” Brookings Papers on Economic Activity 1, pp.327-362.

Lamoreaux, Naomi (1985), The Great Merger Movement in American Business, Cambridge: Cambridge University Press.

Lawrence, Robert Z., Albert Bressand and Takatoshi Ito (1996), A Vision for the World Economy: Openness, Diversity and Cohesion, Washington, D.C.: The Brookings Institution.

Lawrence, Robert Z., and Robert E. Litan (1986), Saving World Trade: A Pragmatic Approach, Washington, D.C.: The Brookings Institution.

Lewis, Cleona (1938), America's Stake in International Investments, Washington, D.C.: The Brookings Institution. 
Lipsey, Robert (1999), "U.S. Foreign Trade and the Balance of Payments, 1800-1913" in Lance Davis and Stanley Engerman (eds.) Cambridge Economic History of the United States, New York: Cambridge University Press.

Lipsey, Robert, Magnus Blomstrom, and Eric Ramstetter (1998), "Internationalized Production in World Output" in Robert E. Baldwin, Robert E. Lipsey, and J. David Richardson (eds.) Geography and Ownership as Bases for Economic Accounting, Chicago: University of Chicago Press.

Lundgren, Nils-Gustav (1996), "Bulk Trade and Maritime Transport Costs: The Evolution of Global Markets," Resources Policy 22, pp.5-32.

Madden, John J. (1985), British Investment in the United States, 1860-1880, New York: Garland Publishing.

Marichal, Carlos (1989), A Century of Latin American Debt Crises, Princeton: Princeton University Press.

Miller, Victoria (1996), "Exchange Rate Crises with Domestic Bank Runs: Evidence from the 1890's," Journal of International Money and Finance 15, p. 4.

Miller, Victoria (1998), "Domestic Bank Runs and Speculative Attacks on Foreign Currencies," Journal of International Money and Finance 17, p. 2.

Miranti, Paul J., Jr. (1990), Accountancy Comes of Age: The Development of an American Profession 188-1940, Chapel Hill: University of North Carolina Press.

Neal, Larry (1992), The Rise of Financial Capitalism: International Capital Markets in the Age of Reason, Cambridge: Cambridge University Press.

Oberholtzer, Ellis Paxson. (1907), Jay Cooke, Philadelphia: G.W. Jacobs.

O’Rourke, Kevin H., and Jeffrey G. Williamson (1994), "Late Nineteenth Century Anglo-American Factor Price Convergence: Were Heckscher and Ohlin Right?" Journal of Economic History 54 (December), pp.892-916.

O'Rourke, Kevin H., and Jeffrey G. Williamson (1999), Globalization and History: The Evolution of a $19^{\text {th }}$ Century Atlantic Economy, Cambridge: MIT Press.

Previts, Gary John and Barbara Dubis Merino (1979), A History of Accounting in America, New York: Ronald Press, second edition 1998.

Ragnan, Subramanian and Robert Z. Lawrence (1999), A Prism on Globalization: Corporate Responses to the Dollar, Washington, D.C.: The Brookings Institution.

Rauch, James (1999), "Networks versus Markets in International Trade," Journal of International Economics, forthcoming June. 
Rauch, James and Alessandra Casella (1998), "Overcoming Informational Barriers to International Resource Allocation: Prices and Group Ties,” NBER Working Paper 6628 (June).

Rodrik, Dani (1998), “The Debate Over Globalization: How to Move Forward by Looking Backward," unpublished manuscript, Harvard University.

Royal Institute for International Affairs (1937), The Problem of International Investment, London: Oxford University Press.

Sachs, Jeffrey and Andrew Warner (1995), "Economic Reform and the Process of Global Integration," Brookings Papers on Economic Activity 1, pp.1-118.

Schott, Jeffrey J. (1994), The Uruguay Round: An Assessment, Washington, D.C.: Institute for International Economics (November).

Schwartz, Anna (1998), “Asian Banking Crises in the 1990's: All Alike?” NBER.

Simon, Matthew (1966), "The United States Balance of Payments, 1861-1900," Trends in the American Economy in the Nineteenth Century, Vol. 24, Studies in Income and Wealth. Princeton: Princeton University Press for the NBER.

Simon, Matthew (1967), “The Pattern of New British Portfolio Investment, 1865-1914,” in J.H. Adler (ed.), Capital Movements and Economic Development, London: Macmillan, pp.**_**.

Snowden, Kenneth A. (1995), “The Evolution of Interregional Mortgage Lending Channels, 18701940: The Life Insurance-Mortgage Company Connection" in Naomi R. Lamoreaux and Daniel M.G. Raff (eds.), Coordination and Information: Historical Perspectives on the Organization of Enterprise, Chicago: University of Chicago Press, pp.209-246.

Sobel, Robert (1965), The Big Board, New York: Free Press.

Soros, George (1998), The Crisis of Global Capitalism, New York: Public Affairs Books.

Summers, Lawrence H. (1998), "Reflections on Managing Global Integration," presented to the Annual Meeting of the Association of Government Economists, 4 January.

Sykes, Alan O. (1991), "Protectionism as a 'Safeguard': A Positive Analysis of the GATT 'Escape Clause' with Normative Speculations," University of Chicago Law Review 58 (Winter), pp.255-305.

Sylla, Richard and George David Smith (1995), "Information and Capital Market Regulation in Anglo-American Finance," in Michael D. Bordo and Richard Sylla (eds.), Anglo-American Financial Systems, New York: Irwin, pp.170-206.

Taylor, Alan M. (1996), "International Capital Mobility in History: The Saving-Investment Relationship,” NBER Working Paper 5743 (September). 
U.S. Bureau of the Census (1995), U.S. Commodity Exports and Imports as Related to Output: 1993 and 1992, Washington, D.C.: GPO (September).

U.S. Bureau of the Census (1975), Historical Statistics of the United States, Washington, D.C.: GPO.

Wheeler, Mark and Susan Pozo (1997), "Is the World Economy More Integrated than a Century Ago?" American Economic Journal 25, pp.139-154.

Wilkins, Mira, (1970), The Emergence of Multinational Enterprise: American Business Abroad from the Colonial Era to 1914, Cambridge: Harvard University Press.

Wilkins, Mira (1989), The History of Foreign Investment in the United States to 1914, Cambridge: Harvard University Press.

Wilkins, Mira (1998), "Conduits for Long-Term Investment in the Gold Standard Era," unpublished manuscript, Florida International University.

Williams, Jeffrey (1986), The Economic Function of Futures Markets, Cambridge: Cambridge University Press.

Williamson, Jeffrey G. (1998), "Globalization, Labor Markets and Policy Backlash in the Past," Journal of Economic Perspectives 12, pp.51-72.

Wright, Gavin (1990), "The Origins of American Industrial Success," American Economic Review 80, pp.651-668.

Zevin, Robert (1992), "Are World Financial Markets More Open? If So, Why and With What Effects?" in Tariq Banuri and Juliet B. Schor (eds.), Financial Openness and National Autonomy, Oxford: Clarendon Press, pp. 43-83. 
</ref_section> 